\title{
2 Amphibole perspective to unravel pre-eruptive processes 3 and conditions in volcanic plumbing systems beneath intermediate \\ 4 arc volcanoes: a case study from Ciomadul volcano 5 (SE Carpathians)
}

\author{
Balázs Kiss • Szabolcs Harangi • Theodoros Ntaflos • \\ Paul R. D. Mason · Elemér Pál-Molnár
}

\begin{abstract}
Ciomadul is the youngest volcano in the Carpathian-Pannonian region produced crystal-rich high-K dacites that contain abundant amphibole phenocrysts. The amphiboles in the studied dacites are characterized by large variety of zoning patterns, textures, and a wide range of compositions (e.g., 6.4-15 wt $\% \mathrm{Al}_{2} \mathrm{O}_{3}, 79-821 \mathrm{ppm} \mathrm{Sr}$ ) often in thin-section scale and even in single crystals. Two amphibole populations were observed in the dacite: low-Al hornblendes represent a cold $\left(<800^{\circ} \mathrm{C}\right)$ silicic crystal mush, whereas the high-Al pargasites crystallized in a hot $\left(>900{ }^{\circ} \mathrm{C}\right)$ mafic magma. Amphibole thermobarometry suggests that the silicic crystal mush was stored in an upper crustal storage $(\sim 8-12 \mathrm{~km})$. This was also the place where the erupted dacitic magma was formed during the remobilization of upper crustal silicic crystal mush body by hot
\end{abstract}

Communicated by T L. Grove.

B. Kiss · S. Harangi · E. Pál-Molnár

MTA-ELTE Volcanology Research Group, Pázmány Péter sétány 1/C, Budapest 1117, Hungary

B. Kiss $\cdot$ S. Harangi

Department of Petrology and Geochemistry, Eötvös Loránd

University, Pázmány Péter sétány 1/C, Budapest 1117, Hungary

B. Kiss $(\bowtie) \cdot$ E. Pál-Molnár

Vulcano Research Group, Department of Mineralogy,

Geochemistry and Petrology, University of Szeged, Egyetem

utca 2, Szeged 6722, Hungary

e-mail: geobalazs@gmail.com

\section{T. Ntaflos}

Department of Lithospheric Research, University of Vienna,

Althanstrasse 14, 1090 Vienna, Austria

P. R. D. Mason

Department of Earth Sciences, Utrecht University, Budapestlaan 4, 3584 CD Utrecht, The Netherlands mafic magma indicated by simple-zoned and composite amphiboles. This includes reheating (by $\sim 200{ }^{\circ} \mathrm{C}$ ) and partial remelting of different parts of the crystal mush followed by intensive crystallization of the second mineral population (including pargasites). Breakdown textures of amphiboles imply that they were formed by reheating in case of hornblendes, suggesting that pre-eruptive heating and mixing could take place within days or weeks before the eruption. The decompression rim of pargasites suggests around 12 days of magma ascent in the conduit. Several arc volcanoes produce mixed intermediate magmas with similar bimodal amphibole cargo as the Ciomadul, but in our dacite the two amphibole population can be found even in a single crystal (composite amphiboles). Our study indicates that high-Al pargasites form as a second generation in these magmas after the mafic replenishment into a silicic capture zone; thus, they cannot unambiguously indicate a deeper mafic storage zone beneath these volcanoes. The simplezoned and composite amphiboles provide direct evidence that significant compositional variations of amphiboles do not necessarily mean variation in the pressure of crystallization even if the Al-tschermak substitution can be recognized, suggesting that amphibole barometers that consider only amphibole composition may often yield unrealistic pressure variation.

Keywords Amphibole perspective - Intermediate 51 magmas · Magma mixing · Volcano plumbing system • $\quad 52$ Thermobarometry $\cdot$ Amphibole texture and zoning patterns

\section{Introduction}

Eruptions of intermediate (andesitic to dacitic) arc volcanoes are usually preceded by open-system magmatic

$\begin{array}{lll}\text { Journal : Large 410 } & \text { Dispatch : 15-2-2014 } & \text { Pages : } \mathbf{2 8} \\ \text { Article No. : } \mathbf{9 8 6} & \square \text { LE } & \square \text { TYPESET } \\ \text { MS Code : CTMP-D-13-00113 } & \boldsymbol{\sim}_{\mathrm{CP}} & \checkmark \text { DISK }\end{array}$


processes such as magma mixing, cumulate assimilation, and crustal contamination, producing a petrologically complex mixture of minerals and melts (e.g., Humphreys et al. 2006; Reubi and Blundy 2009; Kent et al. 2010). It is essential to understand these processes because they determine the physical state of the erupted magma and as a consequence the style of the volcanic eruption (Ruprecht and Bachmann 2010; Koleszar et al. 2012).

Here, we present the results of a combined textural and chemical (major and trace elements) analyses of amphiboles found in the dacitic rocks of the Ciomadul volcano. The Ciomadul located in the SE Carpathians is the youngest volcano of Carpathian-Pannonian region and referred as a potentially active volcano (Szakács et al. 2002; Harangi 2007; Popa et al. 2012; Szakács and Seghedi 2013). Despite this, very little is known about how the erupted magmas were formed or what triggered their eruptions (Vinkler et al. 2007). Using amphiboles, we could imply the volcanic plumbing system and constrain the pre-eruptive magma chamber processes. Amphibole is a powerful tool as they can record parallel pre-eruptive processes and conditions due to its sensitivity for changing magmatic variables such as temperature, pressure, redox state, $\mathrm{H}_{2} \mathrm{O}$ content, melt composition, and co-crystallizing mineral phases (e.g., Johnson and Rutherford 1989a; Rutherford and Hill 1993; Scaillet and Evans 1999; Bachmann and Dungan 2002; Rutherford and Devine 2003; Sato et al. 2005; Humphreys et al. 2006, 2009b; Thornber et al. 2008; Ridolfi et al. 2010; Krawczynski et al. 2012). Consequently, the careful investigation of their crystal growth stratigraphy can provide an "amphibolic" perspective toward understanding the dynamics and processes of dacitic-andesitic volcanoes before eruptions (Thornber et al. 2008) including Ciomadul.

We investigate the implications of our study for using amphibole to constrain the subvolcanic plumbing systems of andesitic to dacitic arc volcanoes in general. Finally, we discuss the origin, conditions, and processes lead to commonly observed bimodal amphibole populations in intermediate mixed magmas erupted at composite arc volcanoes. Our study highlights that different amphibole thermobarometers can produce essentially different results, which may lead to false interpretations on the magma evolution and architecture of the magma storage system without clear textural control and crystal growth stratigraphy. We point out the deficiency of the Ridolfi's thermobarometric model that yields always the same $\mathrm{p}-\mathrm{T}$ evolution path for amphiboles along their stability curve.

\section{Geological setting}

Ciomadul volcano is located at the southeastern edge of the Carpathian-Pannonian region, and this is the youngest
Fig. 1 a Geological sketch map of the Carpathian-Pannonian region in Eastern-Central Europe. The cross-hatched areas show the Neogene calc-alkaline volcanic rocks (on the surface). b Topographic map of Ciomadul (Csomád) volcano (Karátson et al. 2013). The sample locations are marked by white stars

volcano of this area (Szakács and Seghedi 1995; Szakács et al. 2002; Vinkler et al. 2007; Harangi et al. 2010; Karátson et al. 2013). It is found at the southern termination of the Călimani-Gurghiu-Harghita (CGH) andesitic-dacitic volcanic chain (Fig. 1) that shows a gradually youngling volcanism from 11.3 Ma (Peltz et al. 1987; Pécskay et al. 1995). There was a sharp compositional change in the erupted magmas within the Harghita Mountains around 3 Ma that spatially coincides with a major tectonic line (Trotus line; Harangi and Lenkey 2007; Seghedi et al. 2011). The post-3 Ma magmas at the southern Harghita are more potassic and show different trace element compositions compared with the older rocks in the north (Seghedi et al. 1987; Szakács et al. 1993; Mason et al. 1996). Volcanic eruptions in Ciomadul could have started around $200 \mathrm{ka}$, and the last volcanic event occurred at $31,000 \pm 260$ cal BP. Initially, the volcanism was mostly effusive and a lava dome complex developed called here "old Ciomadul." Later, the volcanic activity became more explosive and as a result of successive phreatomagmatic and subplinian eruptions, the edifice of the "old Ciomadul" was partially destroyed and two deep explosive craters were formed (Szakács and Seghedi 1995; Karátson et al. 2013). The erupted magma remained fairly homogeneous through time and shows high-K dacitic composition (Szakács and Seghedi 1986; Vinkler et al. 1997). The geodynamic background of the CGH volcanism and particularly the volcanic activity of southern Harghita and Ciomadul is still highly debated. Roll-back subduction and gradual break off of the subducted slab and/or gravitational instability and lithospheric delamination was invoked to explain the geodynamics of the area (e.g., Seghedi et al. 2011; Mason et al. 1998; Gîrbacea and Frisch 1998; Chalot-Prat and Gîrbacea 2000; Lorinczi and Houseman 2009; Fillerup et al. 2010; Ren et al. 2012). Whatever is the explanation for the origin of the near-vertical slab beneath this area, the active seismicity in the Vrancea zone as well as the gas chemistry and seismicity beneath Ciomadul (Vaselli et al. 2002; Popa et al. 2012) implies that rejuvenation of the volcanism cannot be unambiguously excluded (Szakács et al. 2002; Harangi 2007; Szakács and Seghedi 2013).

\section{Samples and analytical techniques}

Samples were collected in Ciomadul during several field campaigns. The fresh lava dome rocks and pumices of the explosive eruptions cover most of eruptive events. During 150

$\begin{array}{lll}\text { Journal : } \text { Large } 410 & \text { Dispatch : } \mathbf{1 5 - 2 - 2 0 1 4} & \text { Pages : } \mathbf{2 8} \\ \text { Article No. : } \mathbf{9 8 6} & \square \text { LE } & \square \text { TYPESET } \\ \text { MS Code : } \quad \text { CTMP-D-13-00113 } & \sim_{\text {CP }} & \checkmark \text { DISK }\end{array}$



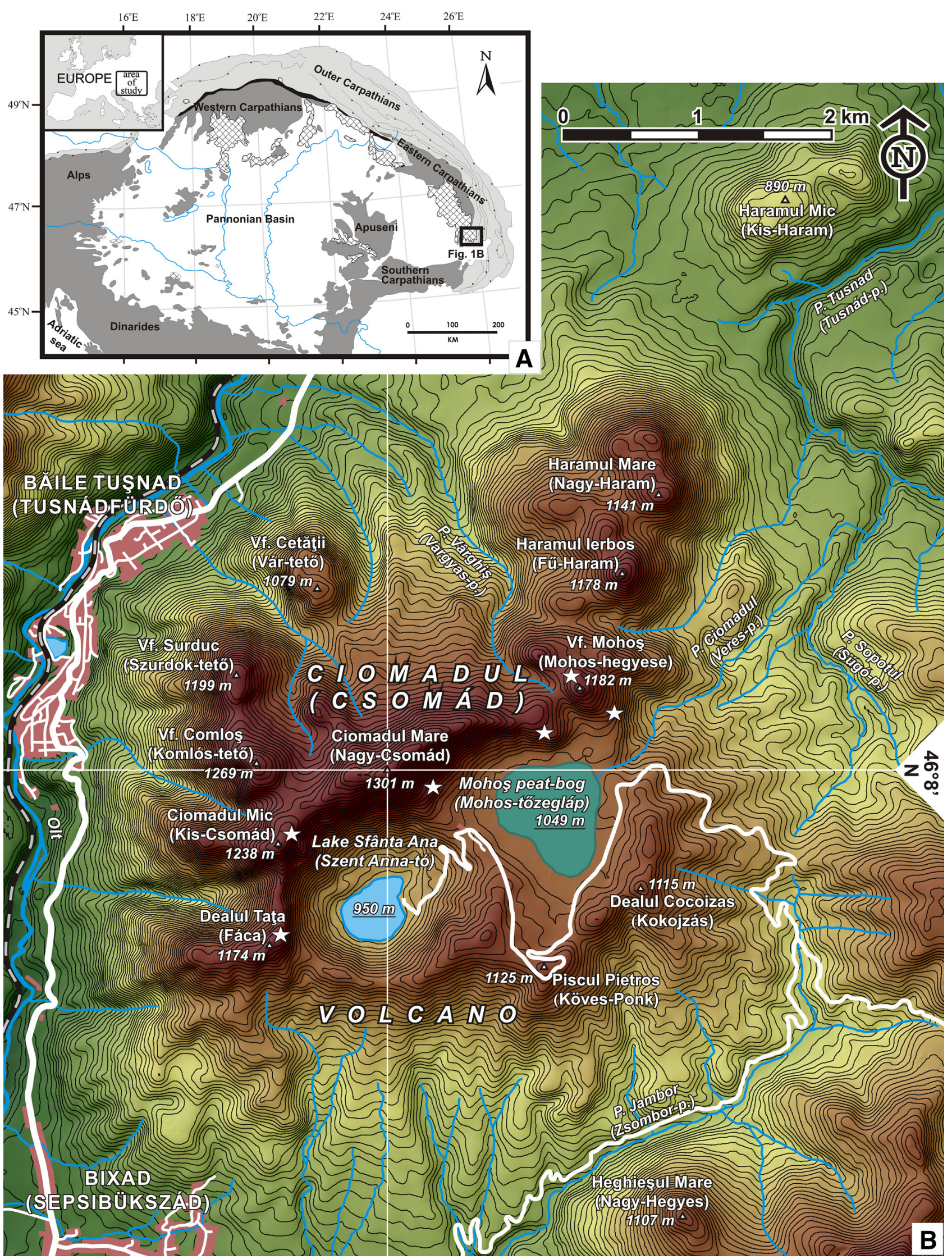

\begin{tabular}{|l|lll|}
\hline Journal : Large 410 & Dispatch : 15-2-2014 & Pages : 28 \\
Article No. : 986 & $\square$ LE & $\square$ TYPESET \\
MS Code : CTMP-D-13-00113 & $\checkmark$ CP & $\checkmark$ DISK \\
\hline
\end{tabular}


this study, we focused on the lava dome rocks collected at

the northern crater rim of the "old Ciomadul." They represent effusive products formed about 100-150 ka and contain the entire mineral assemblage as well as felsic and mafic inclusions found in the Ciomadul dacite. Textural characterization of the mineral phases was performed by combined investigation with petrographic microscope and an AMRAY 1830 I/T6 scanning electron microscope at the Department of Petrology and Geochemistry of the Eötvös Loránd University. The in situ analyses of the mineral phases were carried out using a CAMECA SX100 electron microprobe equipped with four WDS and one EDS at the University of Vienna, Department of Lithospheric Research (Austria). The operating conditions were as follows: $15 \mathrm{kV}$ accelerating voltage, $20 \mathrm{nA}$ beam current, 20 s counting time on peak position, and PAP correction procedure for data reduction. Amphibole and plagioclase crystals were measured with defocused beam $(3-5 \mu \mathrm{m})$. Calibration was based on the following standards: Amelia albite (Na, Si, Al), San Carlos olivine (Mg) (Jarosewich et al. 1980), almandine 112140 (Fe) (McGuire et al.1992), microclin (K) (Jarosewich et al. 1980), and the department's own standards wollastonite (Ca), rutile (Ti), spessartine $(\mathrm{Mn})$, synthetic $\mathrm{Mg}$ chromite $(\mathrm{Cr})$, and $\mathrm{Ni}$ oxide (Ni).

Trace elements in amphibole phenocrysts were measured by LA-ICP-MS using a 193-nm ArF excimer laser ablation system (MicroLas GeoLas 200Q) in combination with quadrupole ICP-MS (Micromass Platform ICP) at Utrecht University (Mason and Kraan 2002) following the methodology described by Harangi et al. (2005). Ablation was performed at a fixed point on the sample with an irradiance of $0.2 \mathrm{GW} \mathrm{cm}^{-2}$, a laser pulse repetition rate of $10 \mathrm{~Hz}$, and an ablation crater diameter of $40-60 \mu \mathrm{m}$. The signal recorded by the ICP-MS during ablation was carefully checked for compositional boundaries to ensure that only data for the amphiboles were integrated. Quantitative concentrations were calculated using NIST SRM 612 as a calibration standard (Pearce et al. 1997) with Ca (previously determined by electron microprobe analysis) as an internal standard element. The USGS reference glass BCR$2 \mathrm{G}$ was continuously measured throughout the analysis of the amphiboles, and the results were within $5-10 \%$ of recommended values. Detection limits were typically in the range $0.01-1 \mu \mathrm{g} \mathrm{g}^{-1}$, and internal precision was $<5 \%$ RSD $(1 \sigma)$ for concentrations above $1 \mu \mathrm{g} \mathrm{g}^{-1}$ and $<15 \%$ RSD $(1 \sigma)$ below $1 \mu \mathrm{g} \mathrm{g}^{-1}$.

\section{Petrology of the dacite}

The studied lava dome rocks are calc-alkaline, high-K dacites $\quad\left(\mathrm{SiO}_{2}=62-68 \mathrm{wt} \% ; \quad \mathrm{K}_{2} \mathrm{O}=3.0-3.6 \mathrm{wt} \%\right)$
Fig. 2 Photomicrographs of amphiboles in the Ciomadul dacite. a Hornblende (hbl) and adjacent embayed quartz (q). b Hornblende with thick opaque rim and touched pair of K-feldspar (kfp); a small pargasite (parg) microphenocryst with thin opaque rim. c, d Pargasite crystal overgrowth on clinopyroxene (cpx) and olivine (ol) crystals, respectively. e Hornblende with thick opaque reaction rim with biotite inclusion (bt) next to simple-zoned amphibole with thin reaction rim; a plagioclase (pl)-pargasite microphenocryst pair. f Hornblende inclusion in a large plagioclase phenocryst; pargasite microphenocrysts and plagioclase laths in the matrix. $\mathbf{g}$ Black opacitized hornblendes in a felsic crystal clot (microdioritic microinclusion) that also contain plagioclase, titanite (tit), zircon (zrn), and intersticial glass; pargasite phenocrysts in the host are also indicated; enlargement (BSE image) of the hornblende in the framed area: close view of the microdioritic inclusion, the hornblende inside is surrounded by clinopyroxene corona set in vesiculated glass $\mathrm{gl}^{*}$. h Simple-zoned amphibole with a "dirty" opacitic core (hornblende), a clear pargasitic rim and a thin opaque reaction rim; apatite (ap) inclusions are present in the core

according to the classification of Gill (1981) and Miyashiro (1974). The erupted dacites are poorly vesicular and porphyritic (phenocrysts content is $30-40$ vol\%), crystal-rich rocks. They contain abundant glomerocrystic aggregates and crystal clots, and the groundmass is totally crystalline. Thus, the texture of the dacite is glomeroporhyritic holocrystalline. The term "phenocryst" is used here for crystals exceeding $300 \mu \mathrm{m}$, whereas "microphenocrysts" are in the size range of $\sim 300-50 \mu \mathrm{m}$. "Microlites" are smaller than $50 \mu \mathrm{m}$. The phenocrysts are (in the order of relative occurrence) plagioclase, amphibole, biotite, clinopyroxene, quartz, K-feldspar, and olivine. The Ciomadul dacite is rich in accessories such as apatite, titanite, and zircon. Allanite is observed occasionally. The groundmass is composed of plagioclase laths, pyroxene microlites, $\mathrm{Fe}-\mathrm{Ti}$ oxides, and $\mathrm{SiO}_{2}$ patches, probably tridymite.

Plagioclase is the most common phenocrystic phase. Two major types were observed: they occur in large glomerocrystic aggregates and as euhedral microphenocrysts (Fig. 2f). The compositional range of the phenocrysts and microphenocrysts overlaps but the An contents of the phenocrysts' cores are lower (An: $34 \pm 8 \mathrm{~mol} \%$ ) than those of the cores of microphenocrysts (An: $52 \pm 4$ mol\%). Amphibole phenocrysts are the most common mafic minerals. Detailed descriptions of amphiboles are presented in the following sections. Biotite phenocrysts are euhedral or subhedral, often rounded and always have a reaction rim. Common inclusions in biotite are apatite, zircon, and glass. Quartz phenocrysts $(<5$ vol $\%$ of the phenocrysts) are always rounded and embayed (Fig. 2a), and occasionally, there are a clinopyroxene-rich rim around them. They are found mostly in the samples with higher proportions of mafic crystal clots, clinopyroxene, and olivine phenocrysts. K-feldspar phenocrysts $(<5 \mathrm{vol} \%$ of the phenocrysts) are also embayed and rounded (Fig. 2b). Some of them are large ( $\sim 5 \mathrm{~mm}$ sized) 

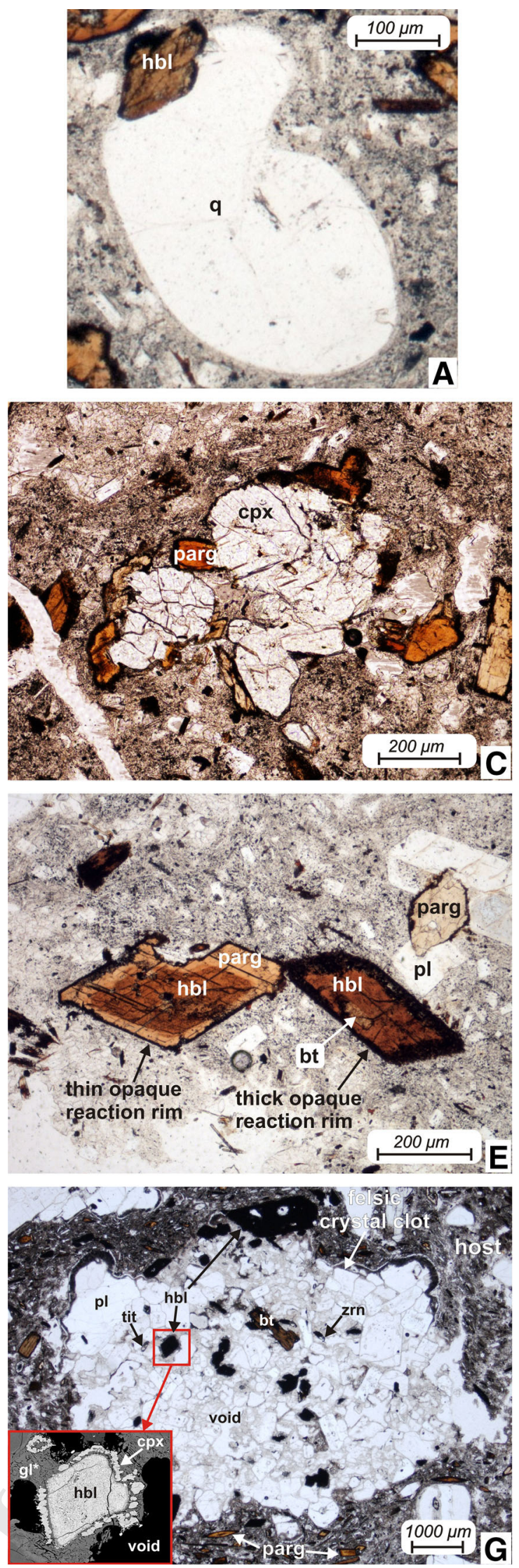
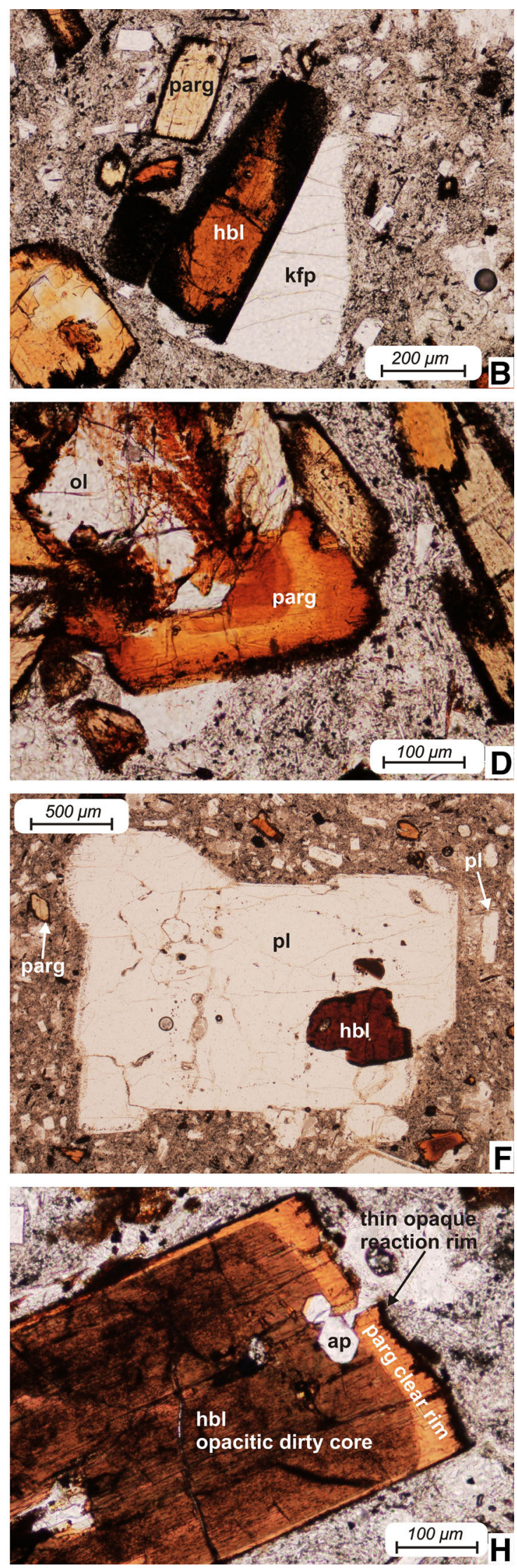

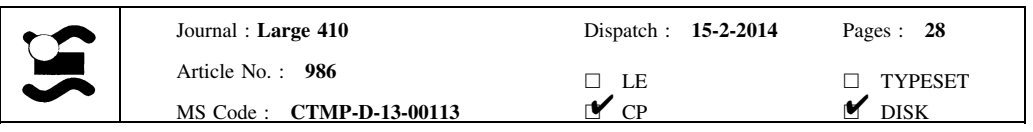


crystals enclosing amphibole, biotite, apatite, titanite, plagioclase, and quartz. Rare olivine crystals are anhedral and usually strongly reacted (Fig. 2d). They are surrounded by fine-grained reaction products (pyroxenes and oxides) and overgrown by amphibole crystals. Tiny euhedral and homogenous $\mathrm{Cr}$-spinel inclusions often occur in the olivines. Clinopyroxenes usually form crystal clots but they also appears as single crystals. They have euhedral or subhedral habit and show various internal zoning. It is often observed that clinopyroxene crystals have rounded edges and they are overgrown by amphibole crystals (Fig. 2c).

The dacites contain various crystal clots. Two larger groups were recognized according to their mineralogy: felsic and mafic clots. Felsic clots are $\sim 1$-cm-sized inclusions consisting dominantly of felsic minerals such as plagioclase $\pm \mathrm{K}$-feldspar \pm quartz. The most common type of the felsic clots is microdioritic (Fig. $2 \mathrm{~g}$ ) composed of plagioclase, amphibole, biotite, titanite, zircon, and apatite. They are texturally similar to adcumulate plutonic rocks but 10-15 vol\% interstitial vesiculated glass is always present. These felsic inclusions could represent a highly crystalline magmatic body in the magma chamber (i.e., crystal mush). Mafic clots contain clinopyroxene or olivine or both with minor amount of plagioclase laths. They are occasionally overgrown by amphibole crystals. (Fig. 2c, d).

\section{Amphibole texture and chemistry}

All of the studied rocks contain two major amphibole types according to their general optical appearances. Amphiboles that are "dirty" and have dark brown-reddish brown pleochroism are termed here "hornblendes" (Fig. 2e). They usually occur as euhedral or subhedral single phenocrysts with no optical zoning and often coexist with K-feldspar, glomerocrystic plagioclase, and quartz (Fig. 2a, b, f) where hornblende is found as intergrowth or inclusions. Amphiboles in the microdioritic inclusions are also hornblendes. These amphiboles contain biotite, apatite, rhyolitic glass, and rarely titanite and plagioclase inclusions (Fig. 2e, h). Hornblendes show various breakdown textures. The second type of amphiboles is "clear" with light brown-yellow pleochroism and will be called "pargasite." They occur as single phenocrysts with optical zoning, but are often found also as overgrowth rim on hornblende, clinopyroxene, and olivine crystals (Fig. 2b-d, h). Amphiboles in the mafic clots are also pargasites. They contain small clinopyroxene, apatite, and sulfide inclusions (Fig. 2d). Pargasites also show breakdown texture, which is described in the following section in more detail. Amphiboles often coexist with plagioclase. The hornblendes typically occur with glomerocrystic plagioclase and pargasites with euhedral plagioclase microphenocrysts (Fig. 2e, f).
Amphibole breakdown textures

Amphibole phenocrysts show different breakdown textures: reaction rims, internal breakdown patches, and clinopyroxene-rich zones or coronas (Fig. 2, 3). Optically, the reaction rims and internal breakdown patches are opacitic. These various textures can be observed in single thin sections and even in single crystals (Fig. 2e, h). The two amphibole groups show marked differences in their breakdown textures. Hornblendes are characterized by a higher degree of breakdown. They are surrounded by a thick, coarse-grained rim consisting of pyroxene, Fe-Ti oxide, feldspar, and glass. Additionally, similar breakdown products also appear within the crystals as patches or along cleavages (internal breakdown patches; Fig. 3). The reaction rim is often present also where the hornblende is in solid-solid contact with other phenocryst (Fig. 3d). The average rim thickness is $\sim 15 \mu \mathrm{m}$ (Fig. 3e) but in some samples, the hornblendes are almost totally replaced by the reaction products (Fig. 2g). Clinopyroxene-rich corona was also observed around some hornblendes, partly in crystal clots (Fig. 2g). Around the pargasite crystals, the reaction rim is finer-grained compared to the breakdown products of hornblendes (Fig. 3c). These rims consist of pyroxenes, $\mathrm{Fe}-\mathrm{Ti}$ oxides, and some feldspar. The reaction rim can be seen only where the pargasite is in direct contact to the matrix.

Some amphiboles show multiple breakdown textures. The core of these crystals is characterized by internal breakdown patches similar as it was observed in the hornblendes, but their outer reaction rim is thin and finegrained as it was observed around pargasites (Fig. 3a, b). Additionally, thin clinopyroxene-rich zone is occasionally observed at the core-rim boundary.

Amphibole major and trace element chemistry, classification

Amphiboles show large intercrystalline compositional variation in major (e.g., $\mathrm{Al}_{2} \mathrm{O}_{3}=6.4-15 \mathrm{wt} \%, \mathrm{MgO}=$ 9.3-17.6 wt\%) and trace elements (e.g., $\mathrm{Ba}=20-500 \mathrm{ppm}$, 326 $\mathrm{Sr}=100-800 \mathrm{ppm})$ (Table 1, 2, 3). In spite of the diversity $\mathbf{A Q 2} 27$ of their textural appearance and variable zoning patterns, the amphiboles can be divided into two separate compositional groups, which correspond to the petrographically determined groups. Hornblendes show low-Al and $\mathrm{Ba}, \mathrm{Sr}, \mathrm{Zr}$ contents, and they are characterized by high $\mathrm{SiO}_{2}$ and $\mathrm{MnO}$, and low $\mathrm{TiO}_{2}$ and $\mathrm{Na}_{2} \mathrm{O}$ contents (Fig. 4, 5) compared with the pargasites. Their low $\mathrm{Al} / \mathrm{Si}(0.19 \pm 0.02)$ ratio, low $\mathrm{Ba}, \mathrm{Sr}, \mathrm{Zr}$ concentrations, and the negative Eu anomaly in the normalized trace element patterns (Fig. 5) suggest that they originated from an evolved, fractionated silicic magma. Pargasite crystals are rich in $\mathrm{Al}$ as well as $\mathrm{Ba}, \mathrm{Sr}, \mathrm{Zr}$, and they have high

\begin{tabular}{|c|c|c|}
\hline Journal : Large 410 & Dispatch : 15-2-2014 & Pages : \\
\hline Article No. : 986 & $\square$ LE & $\square$ TYPESET \\
\hline
\end{tabular}



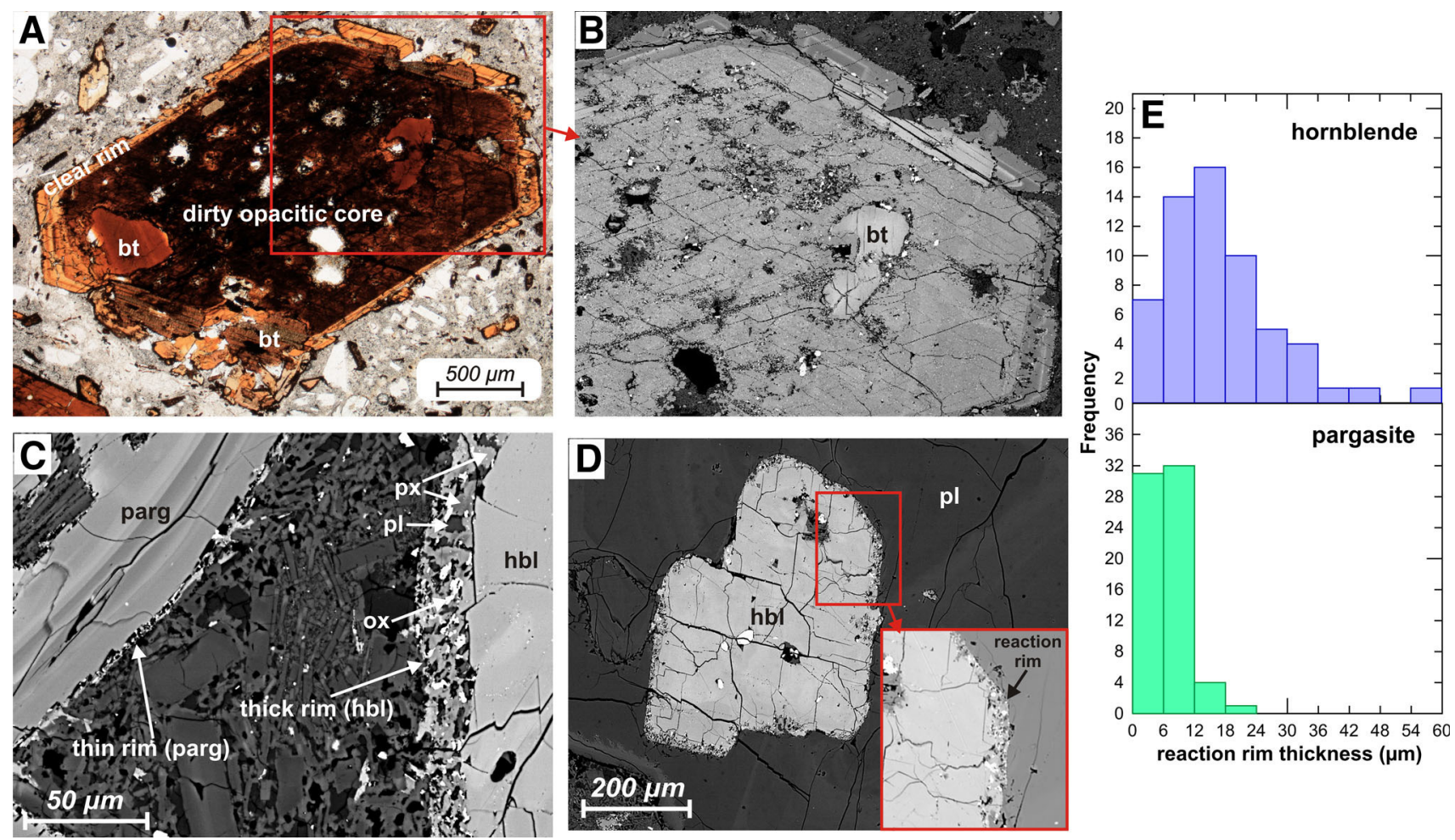

Fig. 3 Pictures of amphibole breakdown textures and histograms of reaction rim thicknesses. a Photomicrograph of an amphibole phenocryst with dirty opacitic core and clear rim (plane-polarized light). b Close-up (BSE image) of the area shown by the rectangle in picture a showing that the internal breakdown patches of the core contain fine-grained reaction products. c Close view of the finegrained thin reaction rim of pargasite and the coarser-grained thick reaction rim of hornblende. $\mathbf{d}$ Hornblende inclusion in plagioclase: the hornblende is surrounded by a reaction rim. e Histogram of the reaction rim thicknesses of the studied amphiboles

Table 1 Representative major element compositions of Ciomadul amphibole crystals

\begin{tabular}{|c|c|c|c|c|c|c|c|c|c|c|}
\hline \multirow{3}{*}{$\begin{array}{l}\text { sample } \\
\text { crystal }\end{array}$} & NCS2-30a & \multirow[t]{2}{*}{ Tc-30a } & \multicolumn{3}{|c|}{ kcs $17-100$} & \multicolumn{3}{|c|}{ kcs $17-100$} & \multirow[t]{2}{*}{$k \operatorname{cs} 17-30$} & \multirow[t]{2}{*}{ Mo2-30b } \\
\hline & \multicolumn{4}{|l|}{ Hornblende: } & & \multicolumn{3}{|c|}{ Pargasite: } & & \\
\hline & $\begin{array}{l}\text { NCS2 am7 } \\
\text { felsic clot }\end{array}$ & $\begin{array}{l}\text { Tc30a_am4 } \\
\text { felsic clot }\end{array}$ & $\begin{array}{l}\text { am_2 } \\
\text { phcr }\end{array}$ & $\begin{array}{l}\text { am_19_1 } \\
\text { phcr }\end{array}$ & $\begin{array}{l}\text { am_19_2 } \\
\text { phcr }\end{array}$ & $\begin{array}{l}\text { am_15 } \\
\text { pher }\end{array}$ & $\begin{array}{l}\text { am_17 } \\
\text { pher }\end{array}$ & $\begin{array}{l}\text { am_13 } \\
\text { mafic clot }\end{array}$ & $\begin{array}{l}\text { 38_am4 } \\
\text { mafic clot }\end{array}$ & $\begin{array}{l}\text { mo2 am4 } \\
\text { mphcr }\end{array}$ \\
\hline $\mathrm{SiO} 2$ & 46.02 & 44.98 & 46.75 & 45.88 & 46.43 & 43.07 & 41.33 & 42.65 & 43.08 & 43.23 \\
\hline $\mathrm{TiO} 2$ & 1.02 & 1.32 & 0.97 & 1.21 & 1.13 & 2.18 & 2.14 & 2.18 & 2.35 & 2.35 \\
\hline $\mathrm{A} 12 \mathrm{O} 3$ & 7.66 & 8.57 & 7.35 & 8.46 & 7.70 & 11.92 & 13.73 & 13.30 & 11.91 & 11.2 \\
\hline $\mathrm{FeO}$ & 14.54 & 15.33 & 14.57 & 14.38 & 14.05 & 9.15 & 9.68 & 7.30 & 7.67 & 10.2 \\
\hline $\mathrm{MnO}$ & 0.39 & 0.42 & 0.47 & 0.39 & 0.38 & 0.12 & 0.09 & 0.11 & 0.09 & 0.14 \\
\hline $\mathrm{MgO}$ & 12.98 & 12.19 & 13.50 & 13.20 & 13.40 & 15.92 & 14.46 & 16.56 & 16.55 & 15.11 \\
\hline $\mathrm{CaO}$ & 11.79 & 11.86 & 11.81 & 11.74 & 11.88 & 11.69 & 11.60 & 11.80 & 11.96 & 11.57 \\
\hline $\mathrm{Na} 2 \mathrm{O}$ & 1.46 & 1.48 & 1.27 & 1.53 & 1.32 & 2.30 & 2.40 & 2.44 & 2.48 & 2.34 \\
\hline $\mathrm{K} 2 \mathrm{O}$ & 0.80 & 0.94 & 0.68 & 0.84 & 0.77 & 0.93 & 0.98 & 1.16 & 0.97 & 0.75 \\
\hline $\mathrm{BaO}$ & n.a. & n.a. & 0.07 & 0.07 & 0.09 & 0.11 & 0.09 & 0.09 & n.a. & n.a. \\
\hline Total & 96.67 & 97.09 & 97.43 & 97.69 & 97.14 & 97.38 & 96.50 & 97.57 & 97.06 & 96.94 \\
\hline
\end{tabular}

$\mathrm{FeO}$, total amount of iron

pher phenocryst, mphcr microphenocryst, n.a. not analyzed

$339 \mathrm{TiO}_{2}$ and $\mathrm{Na}_{2} \mathrm{O}$, and low $\mathrm{SiO}_{2}$ and $\mathrm{MnO}$ contents (Fig. 4, 5).

340 The lack of negative Eu anomaly, along with the high $\mathrm{Al} / \mathrm{Si}$

341 ratio $(0.33 \pm 0.03)$, suggests that these amphiboles crystal-

342 lized from a more primitive, presumably mafic magma. The
$\mathrm{CaO}$ content is similar in both groups and show minor variations. The $\mathrm{MgO}$ concentration of the two groups overlaps but the low-Al amphiboles cluster at lower $\mathrm{MgO}$ than the high-Al amphiboles. The compositional variation can be also large

\begin{tabular}{|l|lll|}
\hline Journal : Large 410 & Dispatch : 15-2-2014 & Pages : 28 \\
Article No. : 986 & $\square$ LE & $\square$ TYPESET \\
& MS Code : CTMP-D-13-00113 & $\sim_{\mathrm{CP}}$ & $\checkmark$ DISK \\
\hline
\end{tabular}


Table 2 Representative trace element compositions of Ciomadul amphibole crystals

\begin{tabular}{|c|c|c|c|c|c|c|c|c|c|c|}
\hline \multirow{3}{*}{$\begin{array}{l}\text { sample } \\
\text { crystal }\end{array}$} & \multicolumn{4}{|c|}{$\mathrm{kcs} 17-100$} & \multirow[t]{2}{*}{$\mathrm{MO} 2$} & \multicolumn{3}{|c|}{ kcs $17-100$} & \multirow[t]{2}{*}{ Mo2 } & \multirow[t]{2}{*}{$\operatorname{Nes} 2$} \\
\hline & \multicolumn{4}{|c|}{ Hornblende: } & & \multicolumn{3}{|c|}{ Pargasite: } & & \\
\hline & $\begin{array}{l}\text { am_2 } \\
\text { phcr }\end{array}$ & $\begin{array}{l}\text { am_19_1 } \\
\text { phcr }\end{array}$ & $\begin{array}{l}\text { am_19_2 } \\
\text { phcr }\end{array}$ & $\begin{array}{l}\text { am_6 } \\
\text { S-Z core }\end{array}$ & $\begin{array}{l}\text { MO2-7 } \\
\text { pher }\end{array}$ & $\begin{array}{l}\text { am_15 } \\
\text { phcr }\end{array}$ & $\begin{array}{l}\text { am_17 } \\
\text { phcr }\end{array}$ & $\begin{array}{l}\text { am_13 } \\
\text { mafic clot }\end{array}$ & $\begin{array}{l}\text { MO2-1 } \\
\text { phcr }\end{array}$ & $\begin{array}{l}\text { NCS2-4 } \\
\text { phcr }\end{array}$ \\
\hline V & 332.17 & 323.88 & 296.97 & 319.30 & 315.27 & 352.49 & 421.31 & 479.17 & 426.33 & 444.71 \\
\hline $\mathrm{Cr}$ & 84.56 & 179.22 & 114.45 & 135.51 & 114.98 & 79.13 & 18.61 & 405.56 & 33.27 & 90.2 \\
\hline $\mathrm{Ni}$ & 50.84 & 45.31 & 37.65 & 39.04 & 56.18 & 47.23 & 53.61 & 56.48 & 28.91 & 22.76 \\
\hline $\mathrm{Rb}$ & 5.53 & 2.66 & 2.45 & 15.21 & 3.49 & 3.83 & 8.08 & 5.53 & 4.58 & 3.94 \\
\hline $\mathrm{Sr}$ & 73.92 & 132.21 & 109.02 & 168.27 & 84.44 & 749.01 & 822.30 & 585.64 & 652.25 & 745.93 \\
\hline Y & 45.84 & 31.06 & 27.87 & 33.50 & 36.22 & 20.85 & 22.76 & 19.04 & 25.64 & 20.53 \\
\hline $\mathrm{Zr}$ & 28.93 & 35.53 & 31.27 & 34.14 & 25.75 & 60.20 & 68.39 & 58.71 & 77.56 & 56.27 \\
\hline $\mathrm{Nb}$ & 18.29 & 18.51 & 16.27 & 16.17 & 19.09 & 15.74 & 10.53 & 19.25 & 14.29 & 14.57 \\
\hline $\mathrm{Ba}$ & 74.77 & 119.66 & 104.02 & 115.83 & 65.24 & 347.92 & 401.52 & 294.31 & 331.53 & 366.85 \\
\hline $\mathrm{La}$ & 15.53 & 23.51 & 16.70 & 18.29 & 12.98 & 14.15 & 15.21 & 11.81 & 15.71 & 11.38 \\
\hline $\mathrm{Ce}$ & 54.25 & 77.01 & 61.27 & 60.10 & 48.76 & 46.91 & 50.42 & 38.50 & 47.35 & 37.01 \\
\hline $\operatorname{Pr}$ & 9.04 & 12.34 & 9.15 & 9.47 & 8.18 & 8.08 & 8.51 & 6.59 & 7.75 & 6.38 \\
\hline $\mathrm{Nd}$ & 40.52 & 48.18 & 39.35 & 41.16 & 36.65 & 35.74 & 39.78 & 28.08 & 37.64 & 30.53 \\
\hline $\mathrm{Sm}$ & 10.74 & 9.89 & 7.66 & 9.31 & 8.35 & 9.04 & 10.00 & 7.71 & 8.84 & 7.45 \\
\hline $\mathrm{Eu}$ & 2.55 & 2.45 & 2.02 & 2.34 & 1.85 & 3.08 & 3.30 & 2.23 & 2.73 & 2.55 \\
\hline Gd & 9.79 & 9.57 & 8.40 & 8.83 & 7.42 & 7.34 & 7.76 & 6.07 & 7.59 & 6.6 \\
\hline Dy & 10.90 & 8.35 & 6.86 & 8.62 & 8.18 & 6.49 & 7.55 & 5.90 & 6.82 & 6.12 \\
\hline $\mathrm{Er}$ & 6.38 & 4.41 & 3.88 & 5.21 & 4.53 & 3.08 & 3.83 & 3.19 & 3.44 & 3.19 \\
\hline $\mathrm{Yb}$ & 5.37 & 3.88 & 3.51 & 4.41 & 4.42 & 2.71 & 2.98 & 2.50 & 2.78 & 2.13 \\
\hline $\mathrm{Lu}$ & 0.74 & 0.53 & 0.43 & 0.64 & 0.65 & 0.32 & 0.43 & 0.32 & 0.44 & 0.32 \\
\hline Hf & 2.45 & 2.13 & 2.02 & 2.34 & 2.29 & 3.19 & 3.19 & 2.87 & 3.27 & 2.87 \\
\hline $\mathrm{Ta}$ & 0.74 & 0.43 & 0.53 & 0.53 & 0.55 & 0.96 & 0.64 & 1.17 & 0.98 & 0.74 \\
\hline $\mathrm{Pb}$ & 3.08 & 1.70 & 2.23 & 2.02 & 2.07 & 2.45 & 4.68 & 1.49 & 1.42 & 1.28 \\
\hline Th & 0.53 & 0.19 & 0.19 & 0.43 & 0.1 & 0.43 & 0.53 & 0.24 & 0.44 & 0.32 \\
\hline $\mathrm{U}$ & 0.14 & 0.04 & 0.05 & 0.12 & 0.04 & 0.09 & 0.22 & 0.04 & 0.15 & 0.05 \\
\hline
\end{tabular}

Pher phenocryst, $S$-Z core core of simple-zoned amphibole

within a single crystal; it can be equal to the whole variation of the phenocrysts (Fig. 4).

According to the classification of IMA (Leake et al. 1997), both amphibole groups belong to the Ca amphiboles. The low-Al amphiboles are dominantly Mg hornblendes and some of them are edenites. The high-Al amphiboles are dominantly pargasites but $\mathrm{Mg}$ hastingsites also occur.

\section{Zoning types and amphibole profiles}

\section{Patchy zoning}

Two types of patchy zoning were distinguished in the dacite (based on BSE images). Type A1 patchy zoning was observed in the backscattered electron images of hornblende phenocrysts. These crystals consist of a core of irregular- shaped bright and dark patches and oscillatory-zoned rims. In the dark patches, melt inclusion with euhedral apatite and mineral inclusions of biotite and apatite are present (Fig. 6). Where it is appreciable, the bright patch looks as a spongy framework with strongly dissolved margin. Brighter portions are richer in $\mathrm{Al}, \mathrm{Ti}$, and $(\mathrm{Na}+\mathrm{K})^{\mathrm{A}}$ and have lower $\mathrm{Mg}$ number than the dark regions (Fig. 8). Oscillatory-zoned rims are characterized by $\mathrm{Al}$ spikes along with increase in $\mathrm{Fe}$, $\mathrm{Ti}$, and $(\mathrm{Na}+\mathrm{K})^{\mathrm{A}}$, and a decrease in $\mathrm{Mg}$ and $\mathrm{Si}$ that follows the dissolution surface (Fig. 7). The other type (type A2) of patchy-zoned amphiboles has rounded patchy-spongy cellular core and dark rim (Fig. 6) and can be observed less frequently. The patches have sharper boundary, and an abrupt shift was observed in their composition. Brighter patches have lower $\mathrm{Al}, \mathrm{Ti},(\mathrm{Na}+\mathrm{K})^{\mathrm{A}}$, and $\mathrm{Mg}$ contents compared to the dark ones (Fig. 8). The dark patches have similar compositions as the rim that contains pyroxene
361

\begin{tabular}{|c|c|c|c|c|}
\hline & Journal : Large $\mathbf{4 1 0}$ & Dispatch & $15-2-2014$ & Pages: 28 \\
\hline & $\begin{array}{l}\text { Article No. : } 986 \\
\text { MS Code : } \quad \text { CTMP-D-13-00113 }\end{array}$ & $\begin{array}{l}\square \text { LE } \\
\sim_{\mathrm{CP}}\end{array}$ & & $\begin{array}{l}\square \text { TYPESET } \\
\boldsymbol{\sim} \\
\text { DISK }\end{array}$ \\
\hline
\end{tabular}




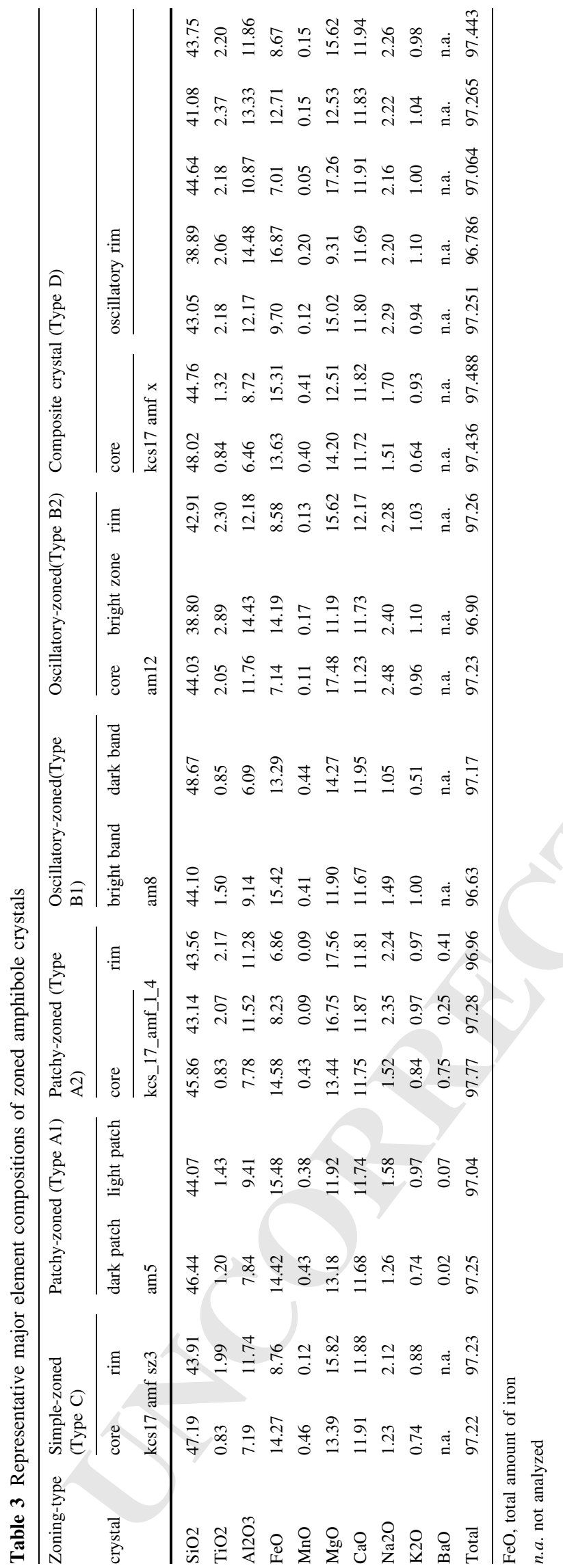

inclusion. The bright patches fall into the compositional field of hornblendes, while the compositions of the dark patches and the rim belong to the pargasite field.

Cyclic zoning

Cyclic zoning (type B) is a commonly observed zoning pattern in Ciomadul amphiboles, and it occurs in two subtypes, i.e., type B1 and type B2 (Fig. 6). The subtypes can be distinguished by their $\mathrm{Al}^{\text {tot }}$ content and the compositional pattern of the growth zones. Type B1 zoning is typical in the hornblende crystals, and these crystals show compositional variation at the low-Al level. Type B1 cyclic zoning is characterized by internal asymmetric growth zones and $\mathrm{Al}$ spikes at their rim. Each growth zone contains a dark $\mathrm{Mg}$ - and Si-rich band and a brighter $\mathrm{Al}-, \mathrm{Fe}-$, $\mathrm{Ti}-,(\mathrm{Na}+\mathrm{K})^{\mathrm{A}}$-rich band. The growth zones are bounded by resorption surfaces (Fig. 7, line 2). Each zone begins with $\mathrm{Al}$-rich and $\mathrm{Mg}$-poor composition but $\mathrm{Al}$ gradually decreases and $\mathrm{Mg}$ increases toward the end of the zone. $\mathrm{Al}$ spikes are thin, symmetrical Al-, Fe-, Ti-, and $(\mathrm{Na}+\mathrm{K})^{\mathrm{A}}-$ rich zones.

Type B2 zoning was observed in pargasite crystals. This zoning type is present in single phenocrysts or in overgrowth rim on hornblende and olivine crystals. Composition of Type B2 crystals varies at the high-Al range. This zoning type is built up by asymmetric growth zones that have resorbed boundaries (Fig. 6). In these crystals, the bright zones show often rounded edges suggesting dissolution. The bright zones enriched in $\mathrm{Al}, \mathrm{Fe}$, and $(\mathrm{Na}+\mathrm{K})^{\mathrm{A}}$, whereas the dark zones are $\mathrm{Mg}$ - and Si-rich (Fig. 7, line 3, 4). Each growth zone begins with $\mathrm{Mg}$-rich and Al-poor composition, and they show gradual change (increasing $\mathrm{Al}$, decreasing $\mathrm{Mg}$ ) toward the end of the growth zone.

Simple-zoned (Type C) amphiboles are frequent in the dacite and show revers geochemical variation toward the crystal rims (Fig. 6). The most important features are the presence of major resorption surfaces with an abrupt shift in $\mathrm{Al}, \mathrm{Ti},(\mathrm{Na}+\mathrm{K})^{\mathrm{A}}$, and $\mathrm{Mg}$ at the core-rim boundary (example shown in Fig. 7, line 5). The bright cores are typically rounded and often spongy cellular, and the cavities are filled by fine-grained reaction products of pyroxene, magnetite, and glass. In extreme cases, the core is totally replaced by these reaction products. The resorbed cores are overgrown by dark amphibole rims enriched in $\mathrm{Al}, \mathrm{Ti},(\mathrm{Na}+\mathrm{K})^{\mathrm{A}}$, and $\mathrm{Mg}$. The composition of the cores overlaps the hornblende field, while the rims have composition akin to pargasites (Fig. 4).

Composite crystals (Type D) are special types of simple411 412 413 414 415 416 417 418 419 420 zoned amphiboles. They (Fig. 6) consist of the same

\begin{tabular}{|l|lll|}
\hline & Journal : Large 410 & Dispatch : 15-2-2014 & Pages : 28 \\
Article No. : 986 & $\square_{\text {LE }}$ & $\square$ TYPESET \\
& MS Code : CTMP-D-13-00113 & $\boldsymbol{\vee}_{\mathrm{CP}}$ & $\boldsymbol{\sim}_{\text {DISK }}$ \\
\hline
\end{tabular}




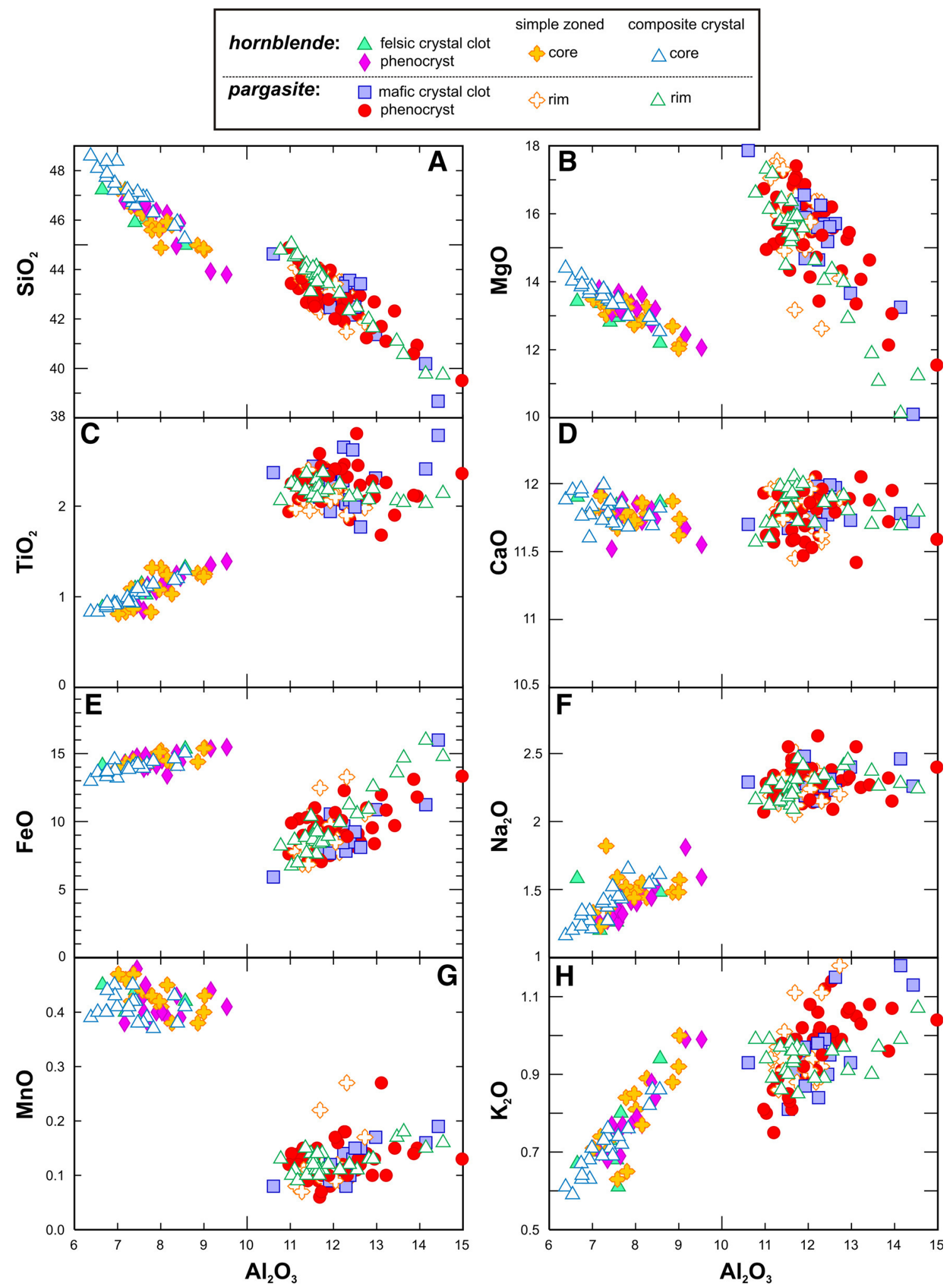

Fig. 4 Major element variation diagrams for the studied amphiboles of the Ciomadul dacite: $\mathrm{Al}_{2} \mathrm{O}_{3}$ versus $\mathrm{SiO}_{2}(\mathbf{a}), \mathrm{MgO}(\mathbf{b}), \mathrm{TiO}{ }_{2}(\mathbf{c}), \mathrm{CaO}(\mathbf{d})$, $\mathrm{FeO}(\mathbf{e}), \mathrm{Na}_{2} \mathrm{O}(\mathbf{f}), \mathrm{MnO}(\mathbf{g})$, and $\mathrm{K}_{2} \mathrm{O}(\mathbf{h})$ contents. All oxides are in wt $\%$

\begin{tabular}{|c|c|c|c|c|}
\hline & Journal : Large 410 & Dispatch & 15-2-2014 & Pages: \\
\hline & $\begin{array}{l}\text { Article No. : } 986 \\
\text { MS Code : } \quad \text { CTMP-D-13-00113 }\end{array}$ & 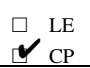 & & $\begin{array}{l}\square \text { TYPESET } \\
\boldsymbol{\sim} \\
\text { DISK }\end{array}$ \\
\hline
\end{tabular}



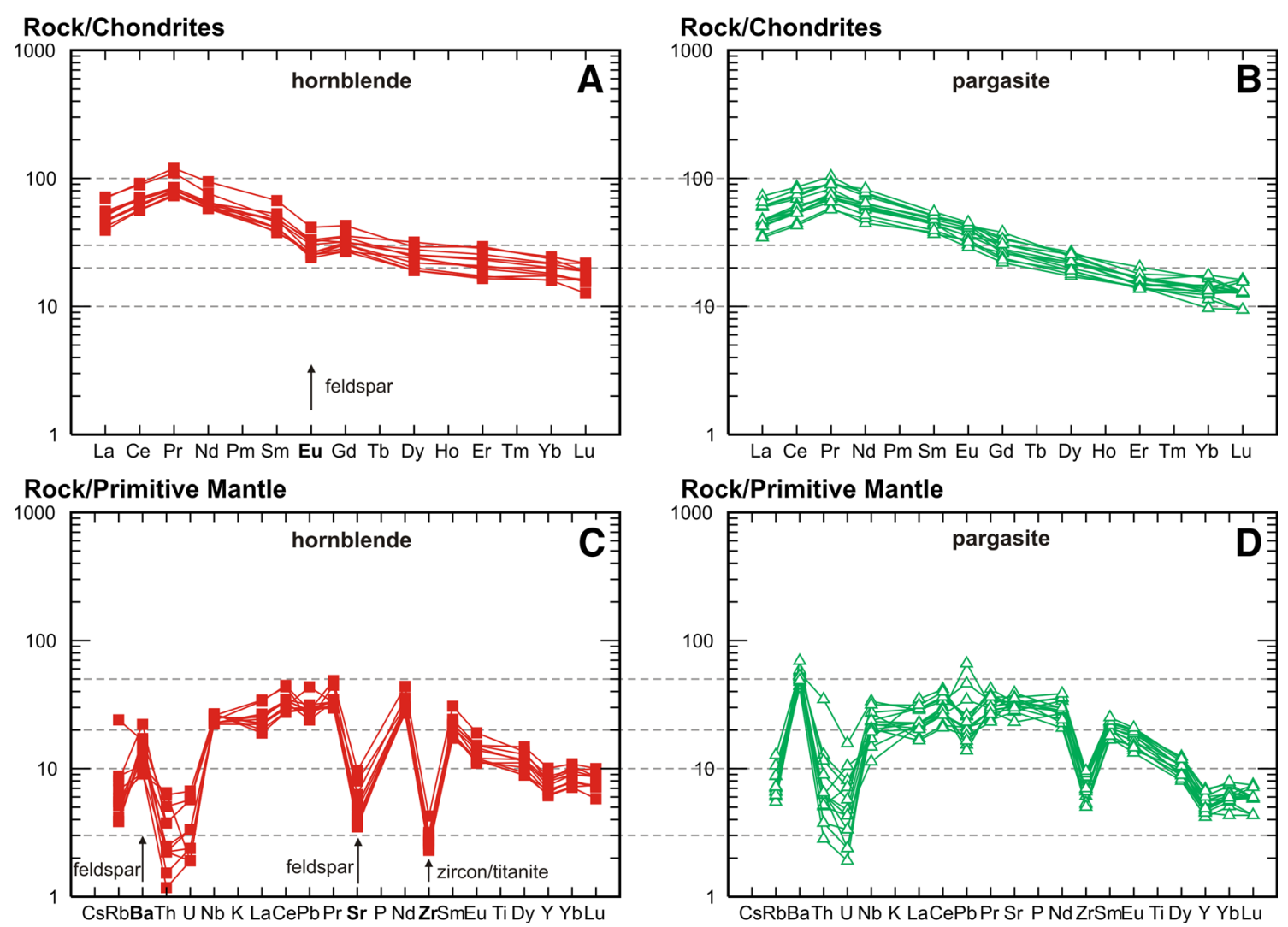

Fig. 5 Chondrite-normalized (Nakamura 1974) REE variation diagrams (a, b) and primitive mantle-normalized (Sun and McDonough 1989) trace element variation diagrams $(\mathbf{c}, \mathbf{d})$ of the studied amphiboles from the Ciomadul dacite

compositions that are seen in the two main amphibole populations with the full range of compositional variation seen even in a single crystal. These crystals are 2-3 mm sized, usually much larger than the other phenocrysts. The crystals can be divided into three parts: a rounded, reacted core, which is surrounded by a thin zone of clinopyroxene and an oscillatory-zoned amphibole rim (Fig. 7, line 6). The crystal core contains mineral inclusion (biotite, apatite, titanite) and compositionally is indistinguishable from hornblende phenocrysts. The rim shows the same type of oscillatory zoning as Type B2 pargasites. The compositional variation in these crystals is particularly remarkable, since it overlaps the whole chemical variability of the amphibole phenocrysts (Fig. 4). Despite the relatively rare occurrence of the composite crystals, they have a great significance concerning the condition of the magma reservoir.

$\mathrm{Al}^{\mathrm{IV}}-\mathrm{Mg \#}$ systematics and substitutions in the zoned amphibole phenocrysts

Three intracrystalline compositional trends can be distinguished in the $\mathrm{Al}^{\mathrm{IV}}-\mathrm{Mg} \#$ diagram (Fig. 8a). Trend 1 is a continuous low-slope negative trend that is observed in the hornblende group including type A1 patchy and type B1 oscillatory-zoned crystals. Trend 2 is also a continuous negative trend, but its slope is much steeper and it is typical for the pargasite group (type B2 and rim of type D). The composition of these crystals is controlled by the $\mathrm{Ti}$ tschermak $\left[\mathrm{Si}^{\mathrm{IV}}+\mathrm{Mg}^{\mathrm{VI}}=\mathrm{Al}^{\mathrm{IV}}+\mathrm{Ti}^{\mathrm{VI}}\right]$ and edenite substitution $\left[\mathrm{Si}^{\mathrm{IV}}+(\square)^{\mathrm{A}}=\mathrm{Al}^{\mathrm{IV}}+(\mathrm{Na}+\mathrm{K})^{\mathrm{A}}\right]$. Some role of the Al-tschermak substitution $\left[\mathrm{Si}^{\mathrm{IV}}+\mathrm{Mg}^{\mathrm{VI}}=-\right.$ $\mathrm{Al}^{\mathrm{IV}}+\mathrm{Al}^{\mathrm{VI}}$ ] can be inferred in the Type $\mathrm{B} 2$ crystals. The third intracrystalline compositional variation of amphiboles is the covariation of $\mathrm{Al}^{\mathrm{IV}}$ and $\mathrm{Mg} \#$ characterizing core-torim variation of Type $\mathrm{C}$ and Type $\mathrm{A} 2$ crystals. It is represented by the positive, non-continuous trend 3 that associates with increasing $\mathrm{Ti}, \mathrm{Al}^{\mathrm{VI}}$, and $(\mathrm{Na}+\mathrm{K})^{\mathrm{A}}$ from core to rim suggests the role of edenite and tschermak substitutions.

\section{Amphibole thermobarometry}

Empirical and experimental studies indicate that amphibole composition can be effectively used to quantify the preeruptive $\mathrm{p}-\mathrm{T}$ conditions during crystallization (e.g., Hammarstrom and Zen 1986; Johnson and Rutherford 1989a;

\begin{tabular}{|c|c|c|c|c|}
\hline & Journal : Large 410 & Dispatch & 15-2-2014 & Pages : \\
\hline & $\begin{array}{l}\text { Article No. : } 986 \\
\text { MS Code : } \quad \text { CTMP-D-13-00113 }\end{array}$ & $\begin{array}{l}\square \\
\boldsymbol{\vartheta}_{\mathrm{CP}}^{\mathrm{LE}} \\
\end{array}$ & & $\begin{array}{ll}\square & \text { TYPESET } \\
\boldsymbol{v} & \text { DISK } \\
\end{array}$ \\
\hline
\end{tabular}


Blundy and Holland 1990; Anderson and Smith 1995; Ernst and Liu 1998; Bachmann and Dungan 2002; Ridolfi et al. 2010). For the estimation of the pre-eruptive conditions, the following strategy was applied: first, we compared the composition of the Ciomadul amphiboles with experimental results that was followed by the application of different thermobarometric techniques. The experimental data set was filtered as suggested by Ridolfi et al. (2010) to avoid inconsistent amphiboles. This comparison could be used as a first approximation of the pre-eruptive parameters.

The composition of the Ciomadul amphiboles and the coexisting minerals is such that several different thermobarometric methods can be applied. The Ridolfi et al. (2010) amphibole thermobarometer called here R2010, and its later extension (Ridolfi and Renzulli 2012, called here as R2012) is calibrated for a wide range of conditions and can thus be applied for both amphibole groups in the Ciomadul dacite. The other advantage of this thermobarometer is that it does not require other minerals to be in equilibrium, and therefore, the intensive parameters can be calculated even along zoning profiles in single amphiboles. Petrographic observations and trace element data indicate that low-Al hornblendes could crystallized along with the mineral assemblage that is required for the amphibole thermobarometric calculation developed by Anderson et al. (2008) (called here as A2008) (RiM69_Ch04_hbld_plag_thermo-jla.xls spreadsheet). This thermobarometry comprises the $\mathrm{Al}^{\text {tot }}$ in amphibole barometry $\left(\mathrm{P}_{\mathrm{Al}-\mathrm{in} \text {-am }}\right)$ (Schmidt 1992; Anderson and Smith 1995) and the amphibole-plagioclase thermometry (Blundy and Holland 1990; Holland and Blundy 1994). Hornblendes often coexist with glomerocrystic plagioclases (Fig. 2f), and they can be considered as cocrystallized phases. On the other hand, pargasites were observed with plagioclase microphenocrysts as touched pairs (Fig. 2e) and were used in the Anderson's calculation in spite of the lack of the necessary mineral phases. The hygro-barometer of Krawczynski et al. (2012) (K2012) was used to estimate the crystallization pressure of pargasites. The results of thermobarometric calculations are summarized in Fig. 9.

\section{Pre-eruptive temperature estimation}

Comparison of the Ciomadul amphiboles with experimental amphibole compositions indicates that the two amphibole groups could crystallize over two distinct temperature ranges (Fig. 10), and this is corroborated by the thermometric calculations. Low-Al hornblendes coexist and probably cocrystallized with a mineral assemblage of biotite, K-feldspar, quartz, plagioclase, titanite, apatite, zircon, allanite, and rhyolithic melt. Experimental studies on similar dacitic rock composition and mineral assemblage (e.g., Fish Canyon tuff
Fig. 6 BSE images showing the zoning patterns and textures of amphiboles in the Ciomadul dacite. Smallest arrows show dissolution surfaces. Compositional profiles of amphiboles are indicated by large thick arrows in Fig. 7. a Type A1 patchy-zoned amphibole; the points indicate the places of chemical measurements from the patchy core. b Type A2 patchy zoning with spongy core in amphibole. Irregular dotted lines indicate the outlines of the patchy cores. $\mathbf{c}$ Type B1 cycliczoned amphiboles (hornblende). d Type B2 cyclic zoning in amphiboles (pargasite). e Type B2 cyclic-zoned amphibole (pargasite). f Type C simple zoning in amphibole. $\mathrm{g}$ Type D composite amphibole crystal with internal breakdown patches in its core. $\mathbf{h}$ Enlargement of the area indicated by the rectangle in picture $\mathbf{g}$ displaying the dissolution surfaces as well as the clinopyroxene zone. Bt biotite, ap apatite, smi silicate melt inclusion, cpx clinopyroxene

dacite, Johnson and Rutherford 1989b) reproduced amphiboles with similar composition at near-solidus temperatures $\left(<800^{\circ} \mathrm{C}\right)$. The amphibole-plagioclase thermometry yields $T_{\text {am-plag }}=732 \pm 27^{\circ} \mathrm{C}$ for mineral pairs, which are in contact with each other and $T_{\text {am-plag }}=730 \pm 15{ }^{\circ} \mathrm{C}$ for the hornblende composition combined with mean plagioclase glomerocrystal core composition. For the same amphibole crystals, the R2010 thermometer gives an average temperature $T_{\mathrm{R} 2010}=821 \pm 20{ }^{\circ} \mathrm{C}$, which is almost $100{ }^{\circ} \mathrm{C}$ higher then the previous values. The R2012 calibration provides a little bit lower temperature $\left(T_{\mathrm{R} 2012}=776 \pm 21^{\circ} \mathrm{C}\right)$ than the $\mathrm{R} 2010$, and this is close to the $T_{\text {amp-plag }}$ within error.

The high-Al pargasites fall into the experimental composition field of amphiboles that was produced at much higher temperatures, i.e., $>900{ }^{\circ} \mathrm{C}$. Thermometric calculations give high crystallization temperature values $\left(T_{\mathrm{R} 2010}=972 \pm 20^{\circ} \mathrm{C}, T_{\mathrm{R} 2012}=944 \pm 20\right)$. The amphibole-plagioclase thermometry indicates lower temperature Tam-plag $=837 \pm 20^{\circ} \mathrm{C}$ for the analyzed pargasite-plagioclase pairs and Tam-plag $=840 \pm 11^{\circ} \mathrm{C}$ for the pargasite composition combined with mean the core composition of plagioclase microphenocrysts.

Estimated depth of the magma storage

Pressure of the amphibole crystallization, i.e., the depth of the magma storage, was also calculated using the same strategy outlined in the previous section. Comparison of our data and the experimental data set suggests amphibole crystallization in the mid- to lower-crust beneath the Ciomadul volcano $(P<400 \mathrm{MPa}, D<15 \mathrm{~km})$. Hornblendes crystallized between 200 and $300 \mathrm{MPa}$ and pargasites between 50 and $400 \mathrm{MPa}$ according to the experimental data set. The so-called Ridolfi barometers (R2010, R2012) indicate that low-T hornblendes crystallized in a shallow magma chamber $\left(P_{\mathrm{R} 2010}=130 \pm 24\right.$ $\mathrm{MPa}, D=5 \pm 1 \mathrm{~km}$ depth) while the high-T pargasites could evolve in a significantly deeper level $\left(P_{\mathrm{R} 2010}=395 \pm 104 \mathrm{MPa}, \quad D=15 \pm 4 \mathrm{~km}\right) \quad$ (Fig. 9). The two barometers give fairly similar pressure range for 

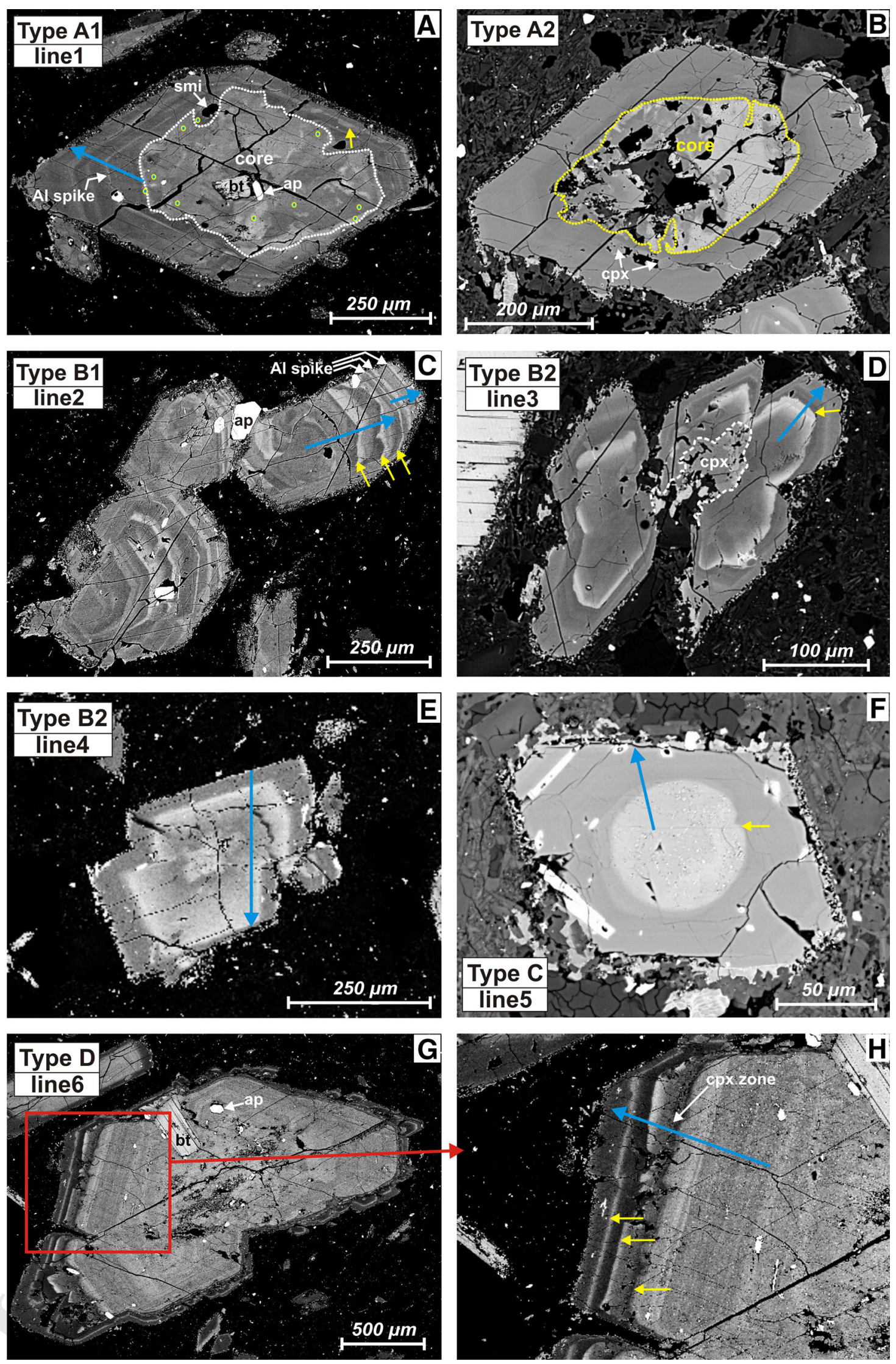

\begin{tabular}{|c|c|c|c|c|}
\hline & Journal : Large 410 & Dispatch & 15-2-2014 & Pages : $\mathbf{2 8}$ \\
\hline & $\begin{array}{l}\text { Article No. : } 986 \\
\text { MS Code : } \quad \text { CTMP-D-13-00113 }\end{array}$ & 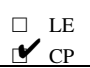 & & $\begin{array}{l}\square \text { TYPESET } \\
\checkmark \text { DISK }\end{array}$ \\
\hline
\end{tabular}


the two distinct amphibole group, respectively; the only difference is the occasional large pressure values (up two $\sim 1,500 \mathrm{MPa}$ ) yielded by the R2012 technique.

On the other hand, the $\mathrm{Al}^{\text {tot }}$ in amphibole barometry $\left(P_{\mathrm{Al}}\right.$ in-am) indicates that the two amphibole group crystallized at the same depth interval. For the low-temperature hornblendes, this calculation indicates deeper storage $(262 \pm 40 \mathrm{MPa}$, $D 10 \pm 2 \mathrm{~km}$ ) than the $\mathrm{R}(2010)$ and $\mathrm{R} 2012$ barometry. In the case of the high-T pargasites, the calculated pressure is lower $(290 \pm 48 \mathrm{MPa}, D 11 \pm 2 \mathrm{~km})$ than the values that were calculated by the R2010 and R2012 equations. The Krawczynski et al. (2012) barometry yields similar pressure for pargasites $(306 \pm 124 \mathrm{MPa}$ )—using the oxygen fugacity values calculated by the R2012 - that is partially overlapping with the results of $\mathrm{Al}^{\text {tot }}$ in amphibole barometry while yielding larger pressure range.

\section{Amphibole $\mathrm{p}-\mathrm{T}-\mathrm{H}_{2} \mathrm{Om}-\mathrm{fO}_{2}$ profiles}

The R2010 and R2012 equations require only the composition of amphibole and thus enable $\mathrm{p}-\mathrm{T}-\mathrm{H}_{2} \mathrm{Om}-f \mathrm{O}_{2}$ profiles to be calculated in zoned amphiboles. We selected representative crystals having the typical zoning patters of the Ciomadul amphiboles to check the intracrystalline variation of the intensive parameters. The R2010 profiles show significant variations in temperature and pressure. In the oscillatory-zoned amphiboles, the temperature variation is about $60-80^{\circ} \mathrm{C}$, while the pressure varies by $100-400 \mathrm{MPa}$ in single amphiboles. The $\mathrm{H}_{2} \mathrm{Om}$ and $f \mathrm{O}_{2}$ profiles also show fluctuations principally in the amphiboles having type $\mathrm{B} 2$ oscillatory zoning. The fluctuations in the intensive parameters clearly mirror the $\mathrm{Al}^{\text {tot }}$ and $\mathrm{Mg}$-number variations along the profiles (Fig. 11, lines 2 and 3). In the simple-zoned amphiboles, a strong and sharp increase in temperature (by $\sim 150{ }^{\circ} \mathrm{C}$ ) and pressure (by more than $200 \mathrm{MPa}$ ) was observed in the rim, but $\mathrm{H} 2 \mathrm{Om}$ and $f^{\mathrm{O}_{2}}$ remain constant. The $\mathrm{R} 2012$ equations also show fluctuations in the estimated parameters but the interpretation of these changes is often controversial (e.g., high $\mathrm{fO}_{2}$ in the low $\mathrm{Mg}$-number zone). Hence, these profiles were not used during the interpretation. The composite crystals show the largest intracrystalline variation in the calculated parameters. The $\mathrm{p}-\mathrm{T}$ values of a single composite crystal cover the whole range that was calculated for the Ciomadul amphibole phenocrysts (Fig. 11, line 6).

\section{Discussion}

The significance of $\mathrm{Al}^{\mathrm{IV}}$ versus $\mathrm{Mg \#}$ interrelation

The large compositional variation in the Ciomadul amphiboles covers the range typical for intermediate magmas. However, unusually in our case, this large
Fig. 7 Compositional profiles- $(\mathrm{Na}+\mathrm{K})^{\mathrm{A}}, \quad \mathrm{Al}^{\mathrm{VI}}, \mathrm{Ti}, \mathrm{Mg}$, and $\mathrm{Al}^{\mathrm{IV}}$ - of the studied amphiboles, which are shown in Fig. 6. Lines 2, 3, 5, and 6 are core-to-rim profiles, and line 4 is a rim-to-rim traverse. Linel the compositions of the patches in the core (Fig. 6a) are plotted as separate points, and the compositions of the $\mathrm{Al}^{\mathrm{IV}}$-richest and $\mathrm{Al}^{\mathrm{IV}}$-poorest points are connected with dotted vertical lines. Dashed vertical lines indicate dissolution surfaces. Line5 the zone boundary of the simple-zoned amphibole (Fig. 6f) is affected by diffusion (d.z.). The typical error is indicated by the symbol size

variability can be detected even in a single crystal (composite amphiboles; Fig. 12). Large chemical variation of amphiboles is often difficult to interpret (De Angelis et al. 2013), because the amphibole composition responds sensitively to changes in many thermodynamic parameters, such as melt composition, pressure, temperature, redox state, and volatile content of the magma and the co-crystallizing mineral phases (e.g., Johnson and Rutherford 1989a; Schmidt 1992; Anderson and Smith 1995; Ernst and Liu 1998; Scaillet and Evans 1999; Bachmann and Dungan 2002; Pichavant et al. 2002; Rutherford and Devine 2003; Sato et al. 2005; Krawczynski et al. 2012). Consequently, the measured compositional variation is a net result of the combination of these parameters. Thus, it is important to determine which parameters are responsible for the observed inter- and intracrystalline compositional variations to avoid misinterpretations of the thermobarometric results (Shane and Smith 2013). The substitution analysis (i.e., studying the correlation of $\mathrm{Al}^{\mathrm{IV}}$ and $\mathrm{Ti}, \mathrm{A}^{(\mathrm{Na}+\mathrm{K})}, \mathrm{Al}^{\mathrm{VI}}$, $\mathrm{Ca}$, etc.) is the most common way to determine the main (intensive) parameters that could control the amphibole crystallization (e.g., Bachmann et al. 2002, Humphreys et al. 2006, De Angelis 2013). Our findings indicate that although this step should not be ignored, a better interpretation can be achieved, when it is completed by the analyses of $\mathrm{Al}^{\mathrm{IV}}$ versus $\mathrm{Mg} \#$ interrelation and the variations of trace element contents.

The changes in the conditions during the magma evolution are reflected principally in the variation in the tetrahedral alumina $\left(\mathrm{Al}^{\mathrm{IV}}\right)$ value and the $\mathrm{Mg}$ number of amphiboles (e.g., Bachmann and Dungan 2002; Rutherford and Devine 2008; Krawczynski et al. 2012), suggesting that these two variables can be useful to recognize and distinguish the main processes that control the growing amphibole composition. The amphiboles of the Ciomadul dacite define two main continuous compositional trends in the $\mathrm{Al}^{\mathrm{IV}}$ versus $\mathrm{Mg}$-number diagram (Fig. 8a). The inverse variation of $\mathrm{Al}^{\mathrm{IV}}$ and $\mathrm{Mg}$ number can be interpreted as coupled substitutions according to the substitution equations that were presented for amphiboles by Vyhnal et al. (1991) and Almeev et al. (2002). These negative compositional trends as well as the positive correlation between $\mathrm{Al}^{\mathrm{IV}}$ and $\mathrm{Ti},(\mathrm{Na}+\mathrm{K})^{\mathrm{A}}, \mathrm{Al}^{\mathrm{VI}}$ indicate the role of edenite $\left[\mathrm{Si}^{\mathrm{IV}}+()^{\mathrm{A}}=\mathrm{Al}^{\mathrm{IV}}+(\mathrm{Na}+\mathrm{K})^{\mathrm{A}}\right]$, Ti-tschermak $\left[\mathrm{Si}^{\mathrm{IV}}+\mathrm{Mg}^{\mathrm{VI}}=\mathrm{Al}^{\mathrm{IV}}+\mathrm{Ti}^{\mathrm{VI}}\right]$, and Al-tschermak $\left[\mathrm{Si}^{\mathrm{IV}}+\right.$ 

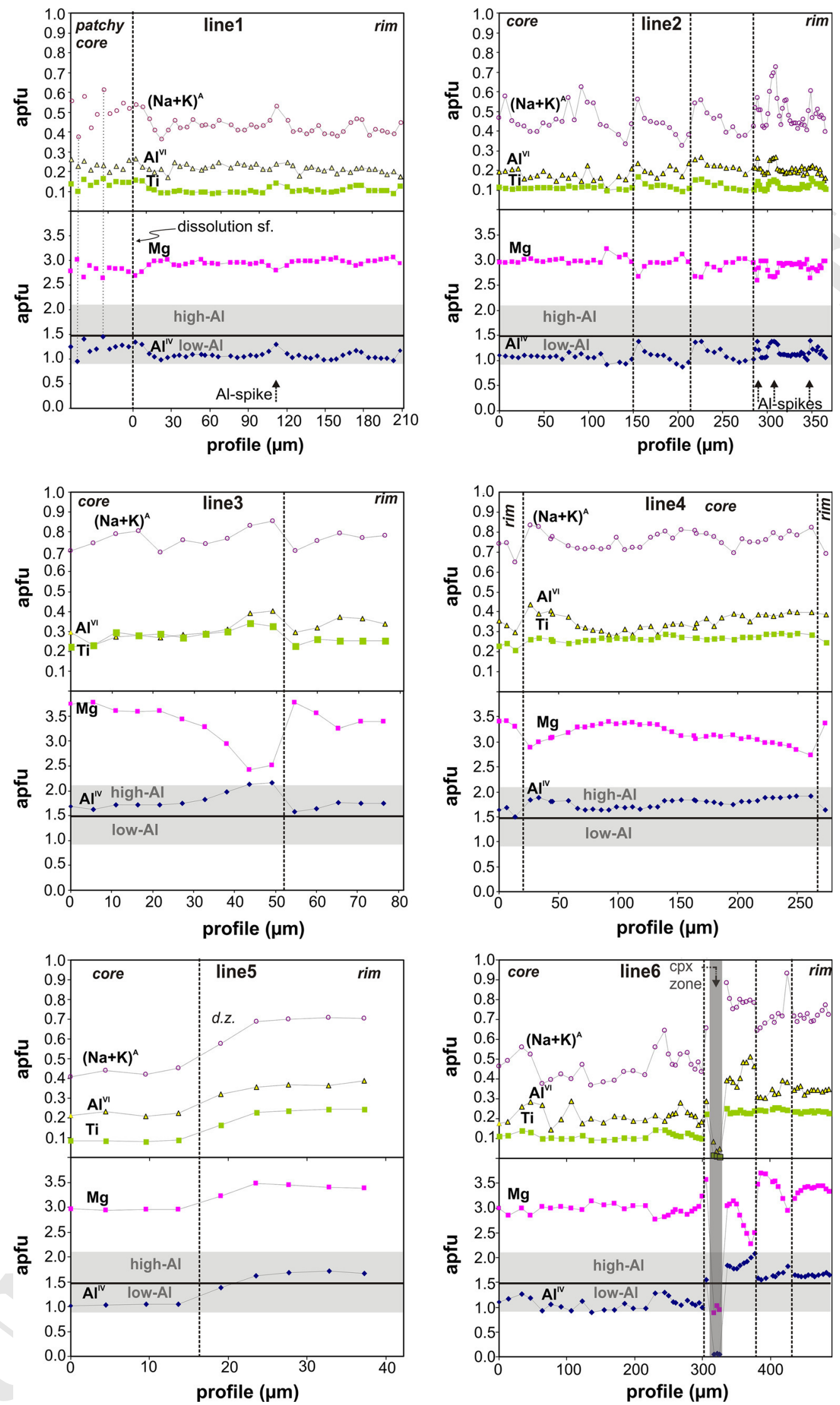

\begin{tabular}{|c|c|c|c|c|}
\hline & Journal : Large 410 & Dispatch & 15-2-2014 & Pages: $\mathbf{2 8}$ \\
\hline & $\begin{array}{l}\text { Article No. : } 986 \\
\text { MS Code : } \quad \text { CTMP-D-13-00113 }\end{array}$ & $\begin{array}{l}\square \text { LE } \\
\boldsymbol{V}_{\mathrm{CP}}\end{array}$ & & $\begin{array}{l}\square \\
\mathcal{v}_{\text {DISK }}^{\text {TYPESET }}\end{array}$ \\
\hline
\end{tabular}


Fig. 8 Plots of $\mathrm{Al}^{\mathrm{IV}}$ versus $\mathrm{Mg} \#\left(\mathrm{Mg} /\left(\mathrm{Mg}+\mathrm{Fe}^{2+}\right)\right)(\mathbf{a})$, $(\mathrm{Na}+\mathrm{K})^{\mathrm{A}}(\mathbf{b})$, Ti $(\mathbf{c})$, and $\mathrm{Al}^{\mathrm{VI}}$ (d) illustrating the substitution mechanisms in the Ciomadul amphiboles. The exchange vectors are indicated in the $\mathbf{b}, \mathbf{c}$, and d diagrams. a Trends 1, 2, 3 show intracrystalliny $\mathrm{Al}^{\mathrm{IV}}-\mathrm{Mg \#}$ systematics of zoned amphiboles. All plotted values are in apfu

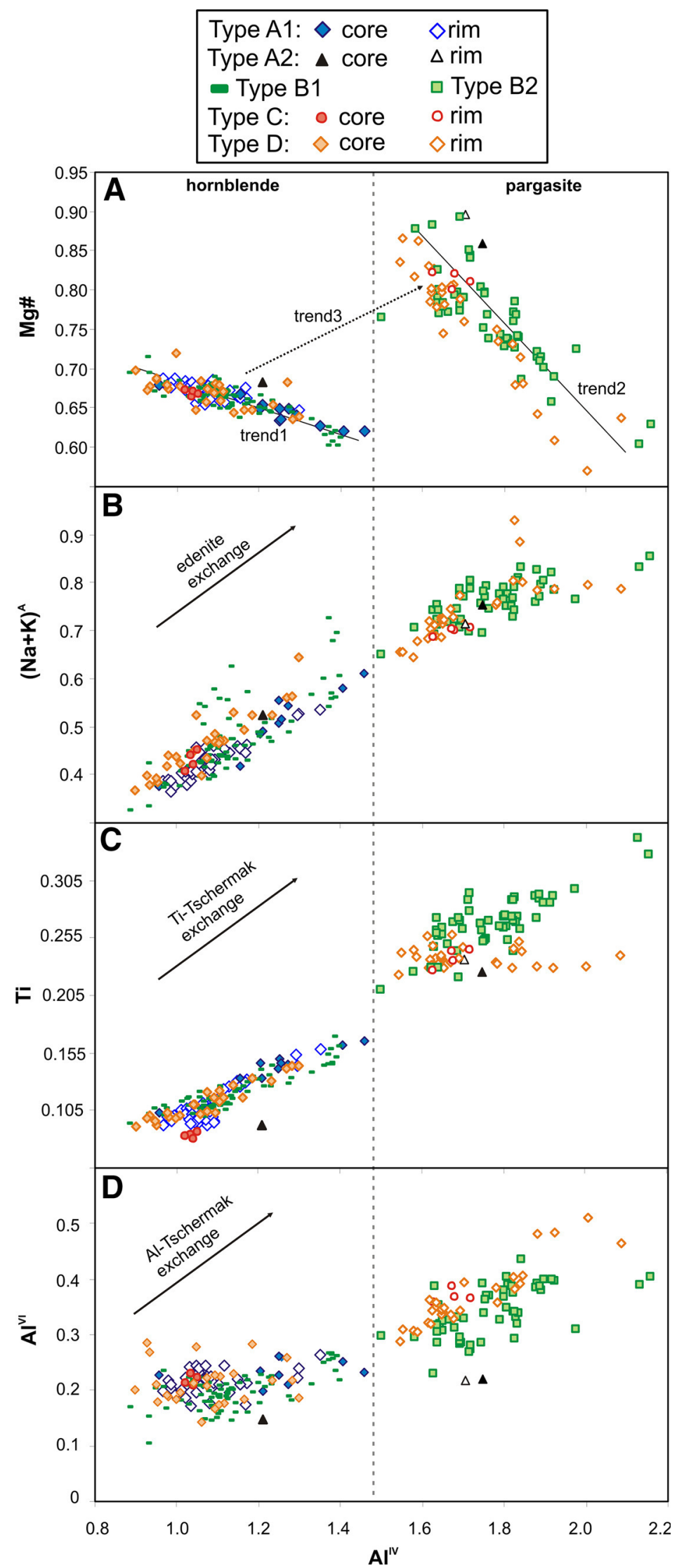

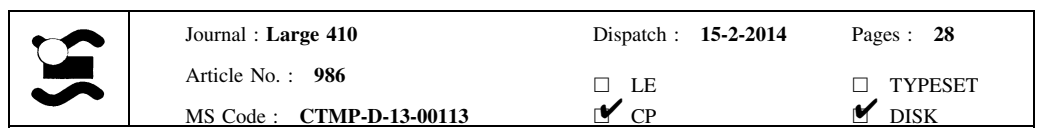


Fig. 9 Temperature-pressure plots $(\mathbf{a}, \mathbf{b})$ of the Ciomadul amphiboles that summarizes the results of amphibole thermobarometry. Inset in b shows various $\mathrm{p}-\mathrm{T}$ paths according to the

thermobarometry and crystallization history of amphiboles, the colored arrows are identical for the different thermobarometers used in determination of the $\mathrm{p}-\mathrm{T}$ paths.

The gray arrow shows our preferred $\mathrm{p}-\mathrm{T}$ path (see details in the text). Dacite solidus is according to Holtz et al. (2001).

The maximum stability of amphiboles in dacite and andesite was determined using the experimental results of

Rutherford and Devine (1988); Johnson and Rutherford (1989a, b); Schmidt (1992); Martel et al. (1999); Sato et al. (1999); Scaillet and Evans (1999); Rutherford and Devine (2003); Costa et al. (2004); Holtz et al. (2005); Sato et al. (2005); Larsen (2006);

Rutherford and Devine (2008);

Simakin et al. (2009). Maximum stability of amphiboles in primitive magmas (basalt, basaltic andesite, $\mathrm{Mg}$ andesite) is based on the experiments of Pichavant et al. (2002); Grove et al. (2003); Barclay and Carmichael (2004); Adam et al. (2007); Krawczynski et al. (2012); Simakin et al. (2012). See text for details

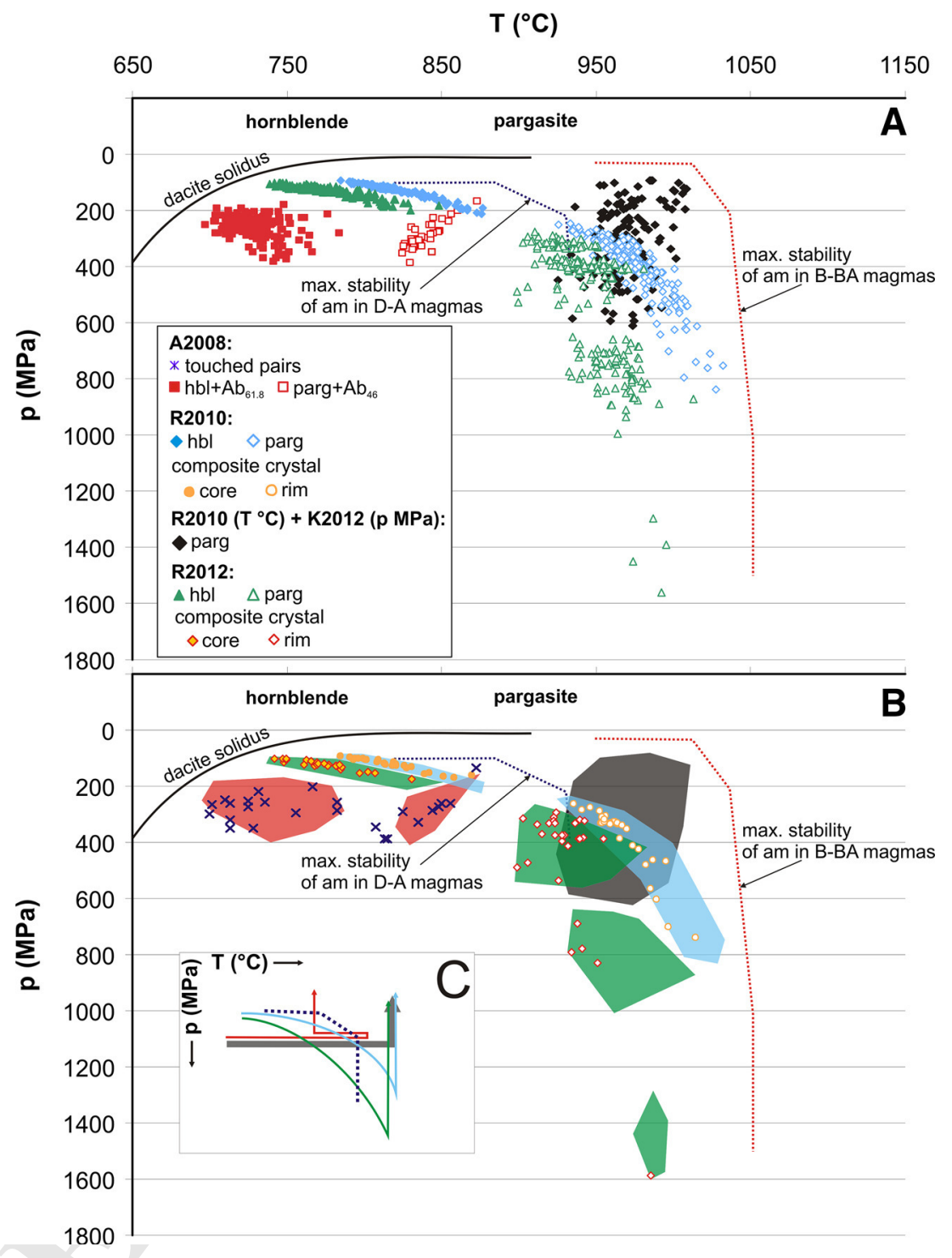

$\mathrm{Mg}^{\mathrm{VI}}=\mathrm{Al}^{\mathrm{IV}}+\mathrm{Al}^{\mathrm{VI}}$ ] substitutions (Fig. 8) as it has been

described also in other localities (e.g., Bachmann and Dungan 2002; Rutherford and Devine 2003; Sato et al. 2005; Rutherford and Devine 2008; Humphreys et al. 2009a, b). These substitutions are sensitive primarily to the crystallization temperature and pressure (e.g., Johnson and Rutherford 1989a; Blundy and Holland 1990; Rutherford and Devine 2003). The clear separation of the two trends (indicated by "trend 3") suggests that the crystallization of amphiboles may have occurred in two different magmas. According to the experimental data, the $\mathrm{Al} / \mathrm{Si}$ ratio of amphibole depends on the Al/Si ratio of the melt (Sisson and Grove 1993; Pichavant et al. 2002). Increasing silica activity in the melt increases the silica content of the coexisting amphibole following the equation pargasite $+4 \mathrm{SiO}_{2}=$ hornblende + albite (Blundy and Holland 1990). As a consequence, the alumina content in the tetrahedral site decreases and therefore the $\mathrm{Al}^{\mathrm{IV}}$ content of the amphiboles could be viewed as a relative differentiation index too (Ridolfi et al. 2010). This can be refined by plotting experimentally produced amphibole compositions on the $\mathrm{Al}^{\mathrm{IV}}$ versus $\mathrm{Mg}$ diagram. Figure 10 shows that low- $\mathrm{T}$ amphiboles crystallized from dacitic magmas have low- $\mathrm{Al}^{\mathrm{IV}}$ and a low-Mg number (blue field). In contrast, amphiboles formed from more mafic magmas at high temperature tend to have higher $\mathrm{Al}^{\mathrm{IV}}$ and higher $\mathrm{Mg}$ numbers. As the silica content of the parent magma decreases, the $\mathrm{Al}^{\mathrm{IV}}$ values of the amphiboles increase (yellow field in Fig. 10). Mafic magma replenishment into a silicic reservoir could cause abrupt decrease in silica activity in the mixed magma. Moreover, mafic input will also increase the $\mathrm{Mg} /$ $(\mathrm{Mg}+\mathrm{Fe})$ ratio in the mixed magma; thus, concomitant increase in $\mathrm{Al}^{\mathrm{IV}}$ and $\mathrm{Mg \#}$ of amphibole will be expected due to magma replenishment. The trace element composition of the studied amphiboles appears to support the mixing model since the low-Al hornblendes have much lower $\mathrm{Sr}, \mathrm{Ba}, \mathrm{Eu}$, and $\mathrm{Zr}$ contents than the high-Al pargasites. As the trace

\begin{tabular}{lll} 
Journal : Large 410 & Dispatch : $\mathbf{1 5 - 2 - 2 0 1 4}$ & Pages : 28 \\
Article No. : 986 & $\square$ LE & $\square$ TYPESET \\
MS Code : CTMP-D-13-00113 & $\sim_{\text {CP }}$ & $\checkmark$ DISK \\
\hline
\end{tabular}




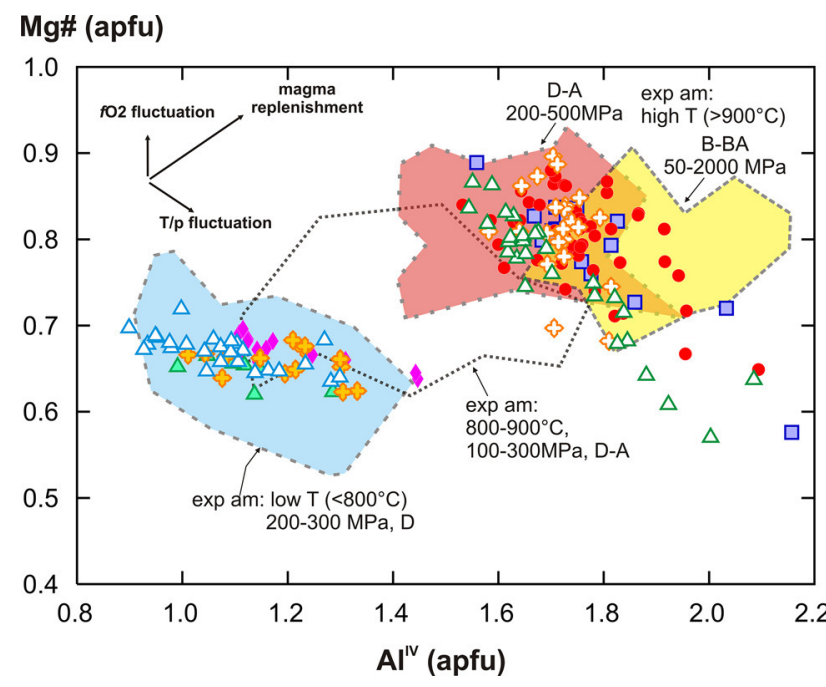

Fig. 10 Plot of $\mathrm{Al}^{\mathrm{IV}}$ versus $\mathrm{Mg} \#$ showing the $\mathrm{Al}^{\mathrm{IV}}-\mathrm{Mg} \#$ systematics of Ciomadul and experimental amphiboles. Symbols (for Ciomadul amphiboles) as in Fig. 4. The black arrows at the upper left edge indicate the interpretation of $\mathrm{Al}^{\mathrm{IV}}-\mathrm{Mg} \#$ systematics of amphiboles (for details, see text). Experimental results were filtered by the method of Ridolfi et al. (2010). High- and low-temperature experimental amphiboles can be separated in the plot. The starting materials used in the experiments are also indicated (D: dacite, A: andesite, BA: basaltic andesite, B: basalt). Results of the following experiments are plotted: Rutherford and Devine (1988); Johnson and Rutherford (1989a, b); Schmidt (1992); Martel et al. (1999); Sato et al. (1999); Scaillet and Evans (1999); Pichavant et al. (2002); Grove et al. (2003); Rutherford and Devine (2003); Barclay and Carmichael (2004); Costa et al. (2004); Holtz et al. (2005); Sato et al. (2005); Larsen (2006); Adam et al. (2007); Rutherford and Devine (2008); Simakin et al. (2009); Krawczynski et al. (2012); Simakin et al. (2012)

686

687

688

689

690

691

692 element content is primarily influenced by the composition of the coexisting melt, the observed differences indicate that the two amphibole populations in the Ciomadul dacites were formed in different magmas. Similarly, positive $\mathrm{Al}^{\mathrm{IV}}-\mathrm{Mg} \#$ trends in amphiboles were reported at other volcanoes (e.g., Soufriere Hills, Humphreys et al. 2009a; Unzen, Sato et al. 2005) where compositional mixing was detected (Nakamura 1995; Murphy et al. 2000).

\section{Interpretation of amphibole thermobarometry}

Application of various amphibole thermometers indicates that the hornblendes in the Ciomadul dacite crystallized at much lower temperature than the pargasites, but they yield different temperature ranges for each population. According to the amphibole-plagioclase thermometry, the hornblendes crystallized at almost $100{ }^{\circ} \mathrm{C}$ lower temperature than it is indicated by the R2010 thermometer. This difference is notable even if we consider the relatively large error of the thermometers $\left(T_{\text {am-plag }}\right.$ error $=40{ }^{\circ} \mathrm{C}$ according to Holland and Blundy (1994), and $T_{\mathrm{R} 2010}$ error $=22{ }^{\circ} \mathrm{C}$ according to Ridolfi et al. (2010)). Experimental works on the dacitic rocks of the Fish Canyon Tuff resulted in amphiboles and coexisting mineral assemblage similar to the Ciomadul rocks at low temperatures $\left(\sim 740^{\circ} \mathrm{C}\right.$; Johnson and Rutherford 1989b). Thus, the R2010 thermometry appears to overestimate the crystallization temperature of the Ciomadul hornblendes but the R2012 yields more appropriate results. Consequently, the hornblendes crystallized below $800{ }^{\circ} \mathrm{C}$ may be at $\sim 730{ }^{\circ} \mathrm{C}$ as indicated by amphibole-plagioclase thermometry. For the high-Al amphiboles (pargasites), the amphibole-plagioclase thermometer gives consistently lower crystallization temperature than the R2010 and R2012. This is corroborated by the comparison with the experimental data set (Fig. 10) and is in agreement with the suggestion of Blundy and Cashman (2008) who claimed that this thermometry is not so accurate for amphiboles with such high-Mg number as shown by the Ciomadul pargasites. On the other hand, the results of the R2010 and R2012 thermometers are in agreement with the experimental data and most likely indicate the crystallization temperature $\left(940-980{ }^{\circ} \mathrm{C}\right)$ of the pargasites. Thus, careful evaluation of the thermometric results indicates that the crystallization of the hornblendes and pargasites in the Ciomadul magma could occur at significantly different (about $\Delta T=200{ }^{\circ} \mathrm{C}$ ) temperatures. Additionally, the Ridolfi et al. (2010) thermometer likely overestimates the crystallization temperature of low-Al (cold) amphiboles.

The barometric calculations can be used to infer the preeruptive magma chamber architecture beneath the Ciomadul volcano. Both the R2010 and R2012 barometry imply a vertically extended magma plumbing system in which the two amphibole populations could crystallize at two separated magma storage levels. According to these barometers, the hornblendes were crystallized at shallow depth $(\sim 5 \mathrm{~km})$, whereas the pargasites were formed at much greater depth, in the middle crust $(\sim 15 \mathrm{~km})$. The $\mathrm{Al}^{\mathrm{IV}}$ versus $\mathrm{Al}^{\mathrm{VI}}$ correlation in the two amphibole populations indicates the role of the pressure-sensitive Al-tschermak substitution during their crystallization and seemingly support these barometric results. However, the crystal growth stratigraphy and the inferred growth history indicate that the crystallization of the high-Al pargasites could not occur deeper than the low-Al hornblendes. Namely, the calculated pressure profiles of simple-zoned and composite amphiboles using the R2010 and R2012 barometer indicate an abrupt increase in the crystallization pressure at the core-rim boundary. This would mean that the rim of these amphiboles would crystallize about $8-10 \mathrm{~km}$ deeper than the cores, and therefore, the low-Al hornblendes should sink many $\mathrm{kms}$ in the magma reservoir not long before the eruption. A similar model (i.e., circulating crystals) was suggested for the origin of the cyclically zoned amphiboles in the Mt. St. Helens dacites, where a vertically elongated, large magma chamber is hypothesized (Pallister et al. 2008). However, no such simple-zoned and composite 
Type B1 - line2

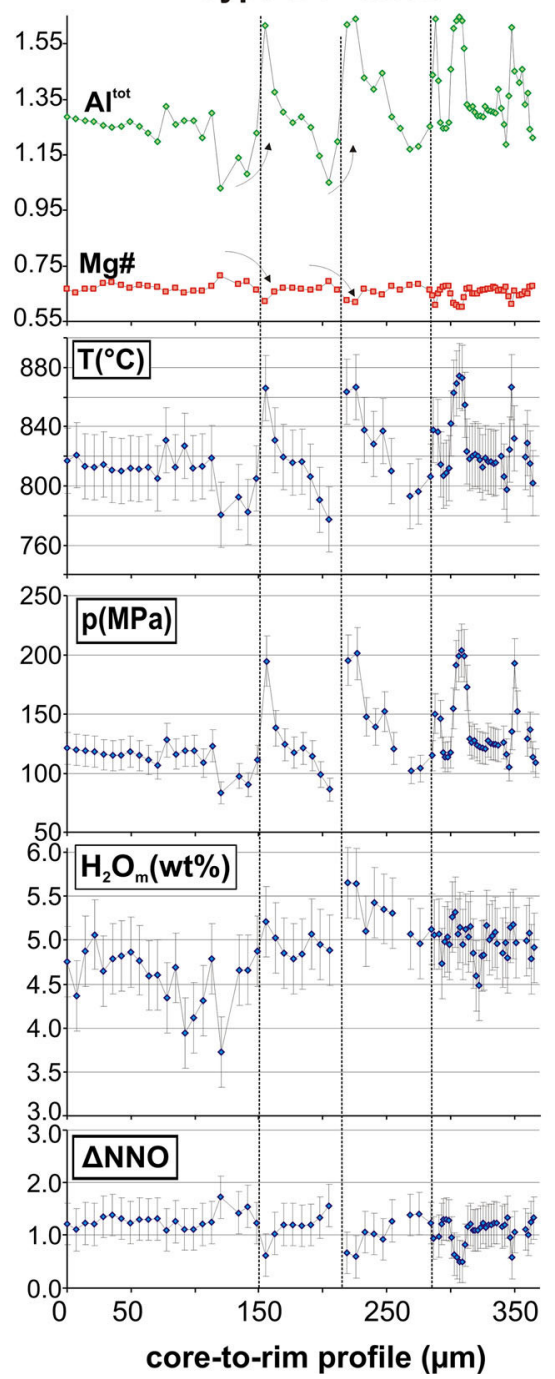

Type B2 - line3

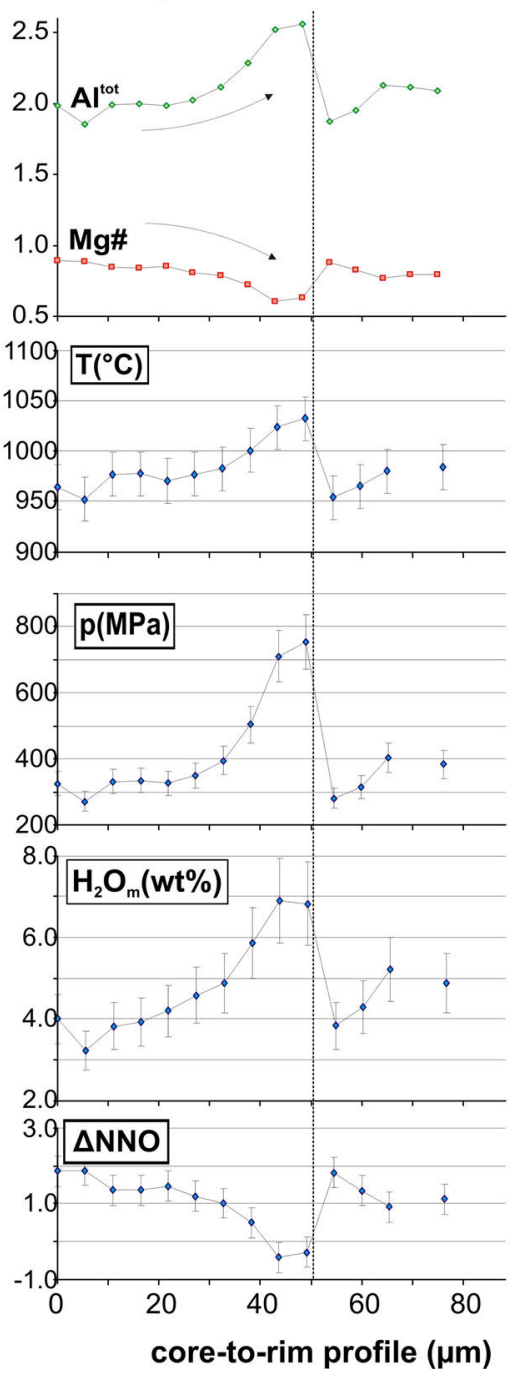

Type D - line6

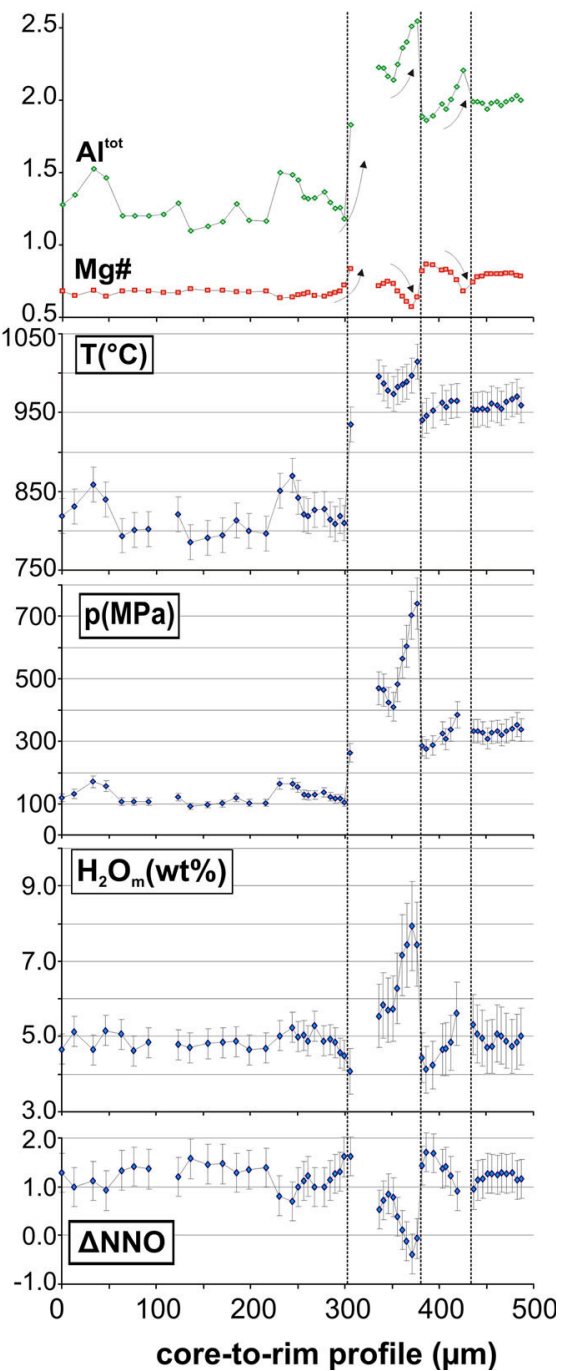

Fig. 11 Temperature (T), pressure (p), melt $\mathrm{H}_{2} \mathrm{O}$ content $\left(\mathrm{H}_{2} \mathrm{O}_{\mathrm{m}}\right)$, oxygen fugacity $\left(f \mathrm{O}_{2}\right)$, and compositional $\left(\mathrm{Al}^{\text {tot }}, \mathrm{Mg \#}\right.$ [apfu]) profiles of three selected amphiboles shown in Fig. $6 c, d$ and $h$, respectively.

amphibole crystals were described in the Mt. St. Helens rocks as we found here in the Ciomadul dacite. Moreover, in our system, the R2010 and R2012 barometry would indicate two separated magma chamber for the bimodal amphiboles, at least $5 \mathrm{~km}$ vertical transportations of crystals seems to be highly unrealistic scenario and rather implies that these barometers significantly overestimate the crystallization pressure of the high-Al pargasites and/or underestimate the crystallization pressure of low-Al hornblendes. Interestingly, the Al-in-amphibole barometry (Schmidt 1992; Anderson and Smith 1995) yields appropriate results (i.e., overlapping pressure values for both hornblendes and pargasites) in spite of the lack of the required coexisting mineral assemblage in the case of the pargasites. Additionally, Grove et al. (2003) and Krawczynski et al. (2012) proposed that the Mg\# of the
Vertical lines indicate dissolution surfaces. The intensive parameters were estimated based on the Ridolfi et al. (2010) formulation

primitive (i.e., near liquidus) amphiboles is related to the $\mathrm{P}_{\mathrm{H} 2 \mathrm{O}}$, and therefore, their hygro-barometer can be used for the pargasites. Although we do not have direct evidence of $\mathrm{H}_{2} \mathrm{O}$ saturation in the Ciomadul magmas, the lack of negative Eu anomaly in the pargasites probably suggests that they are originated from a melt that was too H2O-rich to crystallize plagioclase. Nevertheless, the overlapping result of the $\mathrm{P}_{\mathrm{Al}-\mathrm{in}-\mathrm{am}}$ calculations and the Krawczynski's barometry is notable and likely informative and is in agreement with the crystal growth stratigraphy. All of these suggests that the depth of the main (eruption feeder) magma storage is indicated by the range of the overlapping barometric results of hornblendes and pargasites that is approximately $200-300 \mathrm{MPa}, 8-12 \mathrm{~km}$. An important point is that the simple-zoned and composite crystals provide direct evidence that the significant variation in $\mathrm{Al}$

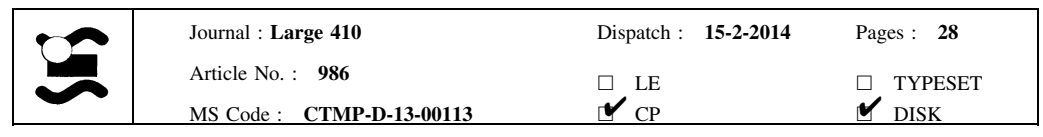




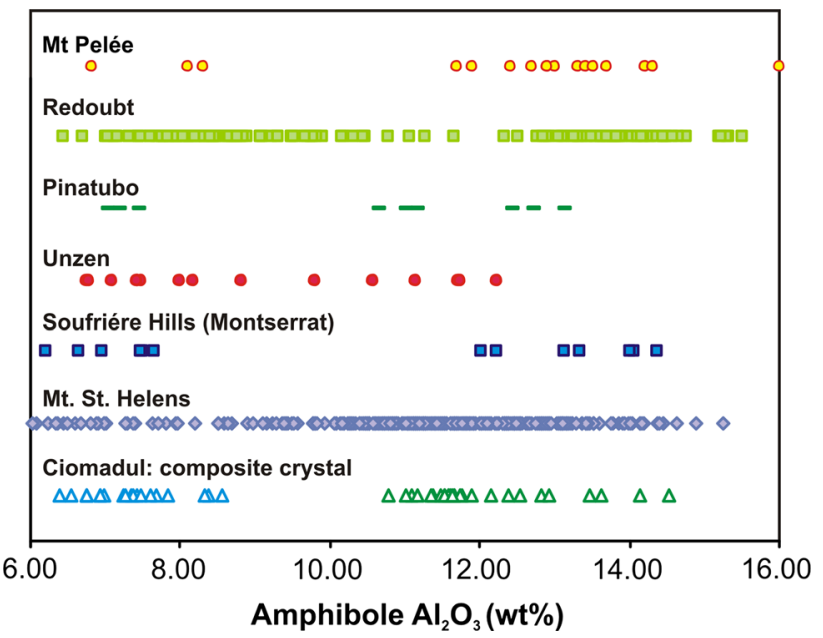

Fig. 12 Compositional variation of amphiboles from selected volcanoes. It is important to note that a single composite crystal of the Ciomadul dacite overlaps almost the entire $\mathrm{Al}_{2} \mathrm{O}_{3}$ range of the other volcanoes. Amphibole compositions are from the following references: Mt. St. Helens, Thornber et al. (2008); Mt. Pinatubo, Pallister et al. (1996); Soufriére Hills (SHV), Murphy et al. (2000); Redoubt, Coombs et al. (2012); Unzen, Sato et al. (2005); Mt Pelée, Pichavant et al. (2002) Ciomadul, this study

content in amphiboles cannot be always explained by crystallization at different pressures/depths even if the Altschermak substitution can be recognized. Furthermore, the low-Al hornblendes - crystallized well inside their stability field-of the Ciomadul dacite also demonstrate that amphiboles do not necessarily crystallize along their stability curve in a narrow stability field as indicated by the thermobarometric formula of Ridolfi et al. (2010). Thus, it can yield unrealistic estimations for the crystallization conditions of crystal mush-derived amphiboles and high-Al amphiboles derived from mafic hybrid magmas.

\section{The origin of amphiboles in the Ciomadul dacites}

Despite the observed diversity in zoning types and the petrographic occurrences of the amphiboles, they can be divided into two coherent compositional groups (Fig. 10). The origin of the two amphibole populations is constrained based on their major and trace element compositions, the coexisting mineral phases, and the thermobarometric results.

Hornblendes in the Ciomadul dacites are characterized typically by low- $\mathrm{Al}^{\mathrm{IV}}$ and low-crystallization temperature, suggesting that they are derived from a cold silicic magma. This is supported by the petrographic observations, because hornblendes are coexistent with a mineral assemblage involving quartz, biotite, K-feldspar, plagioclase, titanite, apatite, and zircon common to silicic magmas. Intergrowths with these minerals (Fig. 2a) unambiguously indicate their common origin. The trace element content of hornblendes shows depletion in $\mathrm{Ba}, \mathrm{Sr}, \mathrm{Zr}$, and Eu (Fig. 5).
These trace elements behave nearly compatible in amphiboles (Viccaro et al. 2007 and references therein); thus, their relative depletion can be explained by co-crystallization of minerals such as plagioclase, K-feldspar, titanite, and zircon. The observed mineral assemblage is often form felsic crystal clots in the studied dacites with up to a few $\mathrm{cm}$ size. The texture of these felsic clots resembles plutonic rock textures, suggesting that they could be derived from a highly crystalline silicic magma body, where the constituting minerals are usually joined by solid-solid contacts. Nevertheless, occurrence of thin interstitial rhyolitic glass implies that this magma body still contained some melt portions, i.e., it could have been a hornblende-bearing crystal mush/sponge residing at shallow depth $(\sim 8-12 \mathrm{~km})$ as shown by the geobarometric calculations.

The high-Al pargasites is characterized by high- $\mathrm{Al}^{\mathrm{IV}}$ content and high crystallization temperature $\left(>900{ }^{\circ} \mathrm{C}\right)$, suggesting that they could crystallize in a hotter, more mafic magma. This is corroborated by the petrographic observations, since pargasites often coexist with Fo-rich olivine and Mg-rich clinopyroxenes (Fig. 2c, d). Furthermore, they have a distinct trace element content with no depletion in the components $(\mathrm{Ba}, \mathrm{Sr}, \mathrm{Zr}, \mathrm{Eu})$ seen in the hornblendes and resemble the trace element composition of the amphiboles found in the mafic volcanic products of Etna (Viccaro et al. 2007). The origin of such high-Al amphiboles is often interpreted as forming in a deep mafic source (e.g., Grove et al. 2003, 2005; Ridolfi et al. 2010; Krawczinsky et al. 2012) and is then transferred and incorporated into a more differentiated magma via mafic replenishment, partly by disaggregation of the mafic enclaves (Humphreys et al. 2009a). This commonly cited scenario, however, does not work for the Ciomadul dacite as it was discussed in the former section. In fact, there are a few studies, which suggest that high-Al amphiboles can crystallize also at low pressures in upper crustal magma storage or even in the conduit (Sato et al. 1999; Coombs et al. 2013) and this condition could be valid for the origin of the Ciomadul amphiboles, as well. The low-pressure formation of the Ciomadul pargasite is supported by further petrographic observation, such as their occurrence around reacted Mg-rich olivine crystals. Coombs and Gardner (2004) showed that a reaction rim is formed around magnesian olivine in contact with silicic magmas. Pargasites are grown on this reaction rim implying that the olivines were already in the silicic magma and pargasites crystallized from a hybrid melt after the mixing of mafic and silicic magmas. Although experimental studies produced high-Al amphiboles such as our pargasites at low pressure (e.g., Sato et al. 1999, Browne 2005, Barclay and Carmichael 2004), direct evidence for low-pressure crystallization of high-Al amphiboles is rarely presented in natural rock samples (Sato et al. 2005).

\begin{tabular}{|c|c|c|}
\hline Journal : Large 410 & Dispatch : $15-2-2014$ & Pages: $\mathbf{2 8}$ \\
\hline $\begin{array}{l}\text { Article No. : } 986 \\
\text { MS Code : CTMP-D-13-00113 }\end{array}$ & $\begin{array}{l}\square \\
\boldsymbol{V}_{\mathrm{CP}}^{\mathrm{LE}} \\
\end{array}$ & $\begin{array}{l}\square \text { TYPESET } \\
\boldsymbol{V} \text { DISK }\end{array}$ \\
\hline
\end{tabular}


Magma chamber processes

Thermometric calculation of the simple-zoned and composite amphiboles from the Ciomadul dacite implies a rim ward temperature rise at least with $150{ }^{\circ} \mathrm{C}$, but it could be as high as $200{ }^{\circ} \mathrm{C}$ if the results of the Holland and Blundy (1994) amphibole-plagioclase thermometry are used for the low-Al hornblendes (Fig. 11, line 6). This is consistent with the experimental data shown in Fig. 10. Such a major increase in temperature can be explained only by intrusion of basaltic magma into the shallow, cold, silicic magma chamber. The strong reheating is reflected also in the complex zoned, composite amphiboles (Fig. 6e, f). At the core-rim boundary, a narrow zone composed of clinopyroxenes is observed that is interpreted as the remnant of the reaction rim around the low-Al amphibole formed due to thermal breakdown. This could mean that the low-Al amphiboles came out of the stability field due to the reheating of the silicic crystal mush body. Experimental data on amphibole stability suggest that amphiboles in dacitic magmas are stable up to about $910{ }^{\circ} \mathrm{C}$ (e.g., Rutherford and Devine 2008) that is approximately $150{ }^{\circ} \mathrm{C}$ higher than the calculated crystallization temperature of the hornblendes. This abrupt temperature increase as well as change in the $\mathrm{Mg}$ number toward the rim is consistent with the injection of fresh mafic magma before eruption. Isobaric reheating experiments of Browne (2005) on dacitic magma produced a breakdown rim around amphiboles with minor pargasite overgrowth. However, the extensive crystallization of the high-Al pargasites in the dacitic magma of Ciomadul needs additional mafic components during reheating. This suggests that mafic magma not only reheated the silicic resident magma but hybridization could have also occurred (e.g., Costa and Singer 2002; Rutherford and Devine 2003). A hybridization zone at the boundary of silicic and mafic magmas is also likely due to the observation that pargasites are present around hornblendes from the silicic magma and also around olivine crystals transported by the intruded mafic magma. Another explanation of this compositional shift could be a concordant increase in $f \mathrm{O}_{2}$ and temperature, since experiments on dacitic magmas indicate that this change in redox state positively influences the amphibole $\mathrm{Mg}$ number and temperature also positively influences the $\mathrm{Al}^{\text {tot }}$ content (e.g., Scaillet and Evans 1999; Costa et al. 2004). According to Scaillet and Evans (1999), a temperature increase from 780 to $900{ }^{\circ} \mathrm{C}$ induces an increase of $\sim 0.4$ apfu in $\mathrm{Al}^{\text {tot }}$ at isobaric conditions. However, in the Ciomadul amphiboles, this variation in $\mathrm{Al}^{\text {tot }}$ is almost the double $(\sim 0.78)$ from core to rim, thus this cannot be produced only by a temperature increase. Furthermore, Costa et al. (2004) reported that high $\mathrm{T}$ and low $\mathrm{fO}_{2}$ promote high-Al content in the experimentally produced amphiboles instead of high $\mathrm{T}$ and high $f \mathrm{O}_{2}$ that needs to increase both $\mathrm{Al}^{\text {tot }}$ and the $\mathrm{Mg}$ number. Thus, it is not likely that the observed core-torim compositional variation can be produced without the involvement of mafic magma replenishment and magma mixing. According to the experimental results of Krawczynski et al. (2012), the high- $\mathrm{Al}^{\text {tot }}$ content in pargasites suggests that the mafic magma could be hot and also water-rich. The mafic replenishment is also supported by the presence of magnesian olivine and clinopyroxene crystals in the erupted dacitic magma.

\section{Origin of the cyclic zoning in amphiboles}

The Ciomadul dacite contains two types of oscillatoryzoned amphiboles: type B1 and type B2. Both types show a negative trend on the $\mathrm{Al}^{\mathrm{IV}}-\mathrm{Mg}$ number diagram (Figs. 8a, 10) indicating that their crystallization was influenced by the fluctuation in intensive thermodynamic parameters. The variation in the $\mathrm{Al}$ content in both zoning types is primarily controlled by the temperature-sensitive edenite and Titschermak substitutions. Temperature profiles of the oscillatory-zoned amphiboles suggest $60-80{ }^{\circ} \mathrm{C}$ variation (Fig. 11, line 2, 3). This temperature change could be explained by convective motion of the magma in the magma chamber due to the temperature contrast (Couch et al. 2001). Oscillatory-zoned amphiboles, which experience convection, may also show Al-tschermak substitution as was demonstrated by Rutherford and Devine (2008). However, in our case, only type B2 crystals show Altschermak substitution, suggesting that type B1 crystals require another explanation. Input/degassing of volatiles could be an alternative model for the formation of oscillatory zoning as was indicated by Humphreys et al. (2009b) and Sato et al. (2005). Experimental data on the Pinatubo dacite show that the $\mathrm{H}_{2} \mathrm{O}$ content of the melt can affect the $\mathrm{Al}^{\mathrm{tot}}$ content of the amphibole (Scaillet and Evans 1999). Furthermore, fluid input/degassing may also affect the redox state of the magma, which influences the amphibole composition as well. Hence, changes in the volatile budget can indeed be reflected in the amphibole composition. Calculation of $\mathrm{H}_{2}$ Omelt and $f \mathrm{O}_{2}$ values along profiles in cyclic-zoned amphibole crystals was performed using Ridolfi et al.'s (2010) equations. These variables show minor fluctuations and change at the dissolution surfaces, suggesting that volatiles might play a role in addition to the temperature change in the formation of type B1 oscillatory zoning (Fig. 11, line 2). Heat can be transferred by volatiles; thus, input of hot fluids into the magma reservoir may be responsible for the temperature variation and dissolution of the growth zones. 

A2) patchy zoning. 2003). surface (Rutherford and Hill 1993).
Patchy zoning can form due to open-system processes or diffusional chemical re-equilibration of a zoned crystal (Streck 2008). In the former case, disequilibrium conditions initiate a spongy-like dissolution of the mineral and parallel or after this, crystallization can occur with a composition reflecting changing conditions. This type of patchy zoning is commonly observed in plagioclase, clinopyroxene, or amphibole (Streck 2008). The most important feature that could help us to identify this texture is the sharpness of the compositional transition between patches and the enclosed mineral or melt inclusions at the boundary of the patches due to rapid re-growth. According to these criteria, both types of the patchy-zoned amphiboles in the Ciomadul dacite could be formed during open-system processes. Type A1 crystals show similar chemical features as the type B1 oscillatory-zoned amphiboles. Additionally, this type of patchy-zoned amphibole often has a type B1 oscillatory rim. Hence, these two zoning types might have been formed due to the same petrogenetic processes. Type A2 patchy-zoned amphiboles show similar chemical variability as the simple-zoned amphiboles suggesting their common origin. Based on these similarities, we can conclude that similar processes, i.e., mafic magma replenishment, could lead to the formation of the (Type

\section{Processes and rates of amphibole breakdown}

The amphiboles in the Ciomadul dacite show diverse breakdown textures, suggesting that they were caused by a combination of processes. Similar diversity of amphibole breakdown textures was also found in the Soufriére Hills andesite, where decompression, heating, and late stage oxidation were all referred to as potential mechanisms leading to amphibole breakdown (Rutherford and Devine

Hornblendes with opacitic breakdown textures in the Ciomadul dacite are often surrounded by high-temperature pargasitic rims (Fig. 2h). Additionally, coarse-grained clinopyroxene rims around hornblendes were also observed (Fig. 2g) providing important evidence of reheating (Rutherford and Devine 2003). The breakdown rim of high-Al pargasites is only developed where these crystals are in direct contact with the matrix, i.e., it should have formed by crystalmelt reaction (Fig. 2e), suggesting that they were formed due to decompression and degassing during magma ascent to the

Experimental works indicate that the extent of amphibole breakdown is a function of the time that the amphibole spends outside its stability field (Rutherford and Hill 1993),although it depends also on the ambient conditions
(Rutherford and Devine 2003; Browne and Gardner 2006). We used the rim thickness data to estimate the time of heating and ascent. According to the different calibrations of the rim formation rate, the pargasites spent a maximum of approximately 12 days outside their stability field. As the rim of pargasites most probably formed via decompression, this estimate may correspond to the magma ascent rate from the magma chamber. The dacites containing hornblendes with the thinnest rims $(\sim 15 \mu \mathrm{m})$ may suggest the timescale of pre-eruption heating and magma mixing. Unfortunately, very little experimental data exist about the rate of thermal breakdown of amphiboles. The available amphibole breakdown rates were calibrated for decompression and suggesting 6-22 days for hornblende breakdown. As the thermal breakdown rate could be much faster Browne (2005), the reaction rim of the Ciomadul hornblendes might have been formed only within a few days, suggesting that the magma chamber was reheated just before the eruption.

Implications for the volcanic plumbing systems beneath intermediate arc volcanoes

Petrological mapping of the magmatic plumbing system beneath active and dormant volcanoes provides constraints on eruption style and aids interpretation of geophysical signals. This information is an essential component of volcanic hazard assessment. The composition, especially the alumina content of amphibole phenocrysts, often shows large variation in the erupted intermediate magmas even in the thin-section scale, and this is commonly interpreted as the result of amphibole crystallization at different pressures and temperatures (e.g., Pichavant et al. 2002; Thornber et al. 2008; Ridolfi et al. 2010; Chambefort et al. 2013; Walker et al. 2013; Costa et al. 2013; and Turner et al. 2013). Results of such studies imply that these volcanoes are underlined by a vertically extended magma storage zone, where the different amphibole populations crystallize at different depths. This zone may consist of separated magma chambers (e.g., Soufriere Hills and Bezymianny, Turner et al. 2013) or a larger, vertically extended magma reservoir (e.g., Mt. Pelée, Pichavant et al. 2002; Santiaguito, Scott et al. 2012; Mt. St. Helens, Pallister et al. 2008). However, in the Ciomadul, dacite single composite crystals show almost the same variation in the $\mathrm{Al}$ content as the amphibole crystals in the entirety of other volcanic systems (Fig. 12). Such crystals have a major importance as they verify that if the composition of amphiboles is controlled by temperature and magma composition at constant pressure (as in our rock samples), the variation in the crystallization pressure/depth detected with amphiboles can be only apparent. This finding highlights that amphibole barometers that consider only amphibole composition such 
Fig. 13 a Comparison of amphibole populations of mixed intermediate magmas from different volcanic arcs defines two separate groups: 1 . cold amphiboles (cold am) derive from a silicic crystal mush, and hot amphiboles (hot am) originate from a hybrid melt that was formed due to fresh mafic intrusion into the mush and mixing of the mafic and silicic magmas, thus they are mafic recharge-related amphiboles. b Crystallization conditions of cold and hot amphiboles according to the Ridolfi et al. (2010) thermobarometer. Data of Mt. Pinatubo (PTB): Pallister et al. (1996); Soufriére Hills (SHV): Murphy et al. (2000); Redoubt (RDT): Coombs et al. (2012); Unzen (UNZ): Sato et al. (2005); Mt Pelée (MPL): Pichavant et al. (2002);

Ciomadul (CIOM): this study
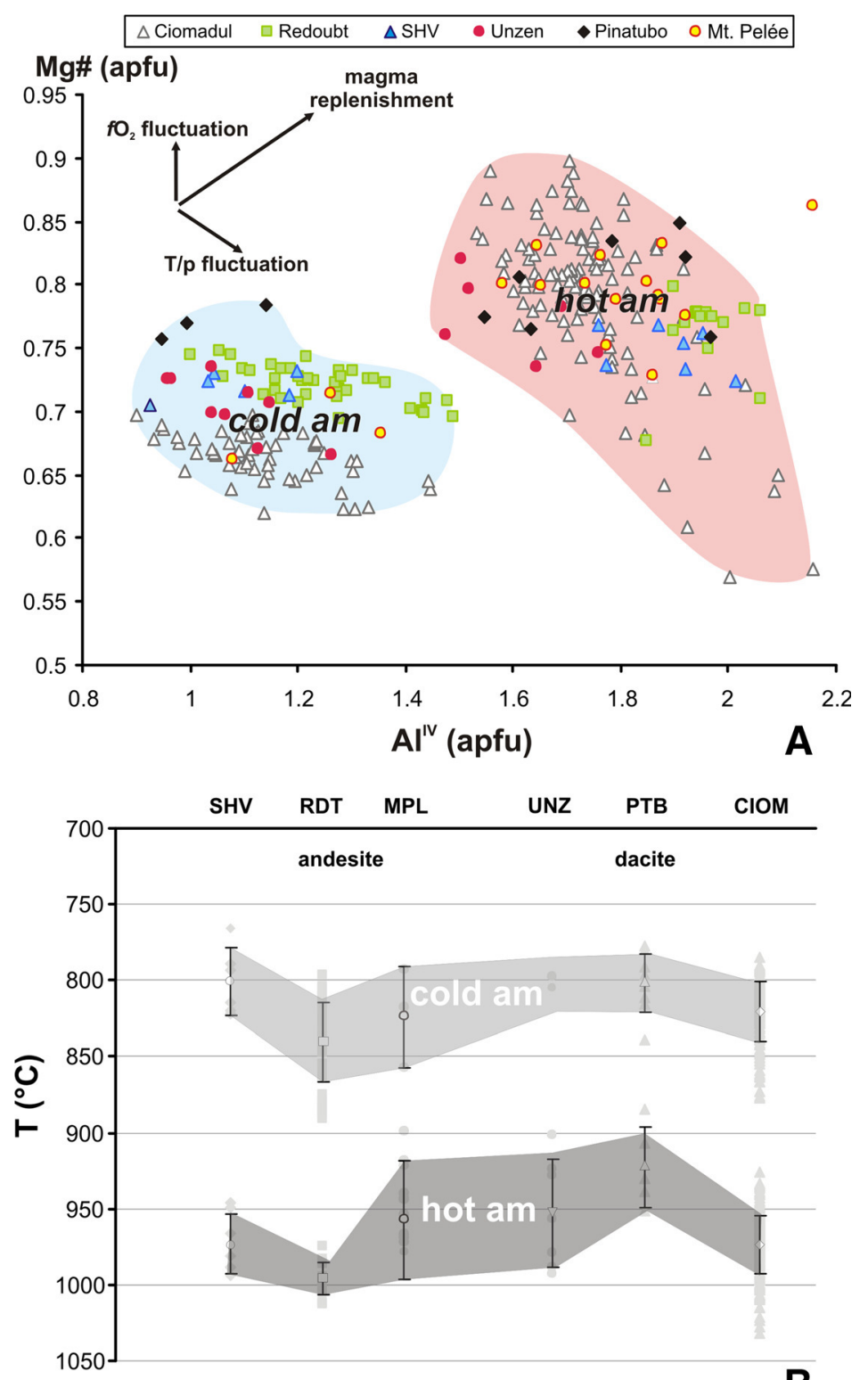

B

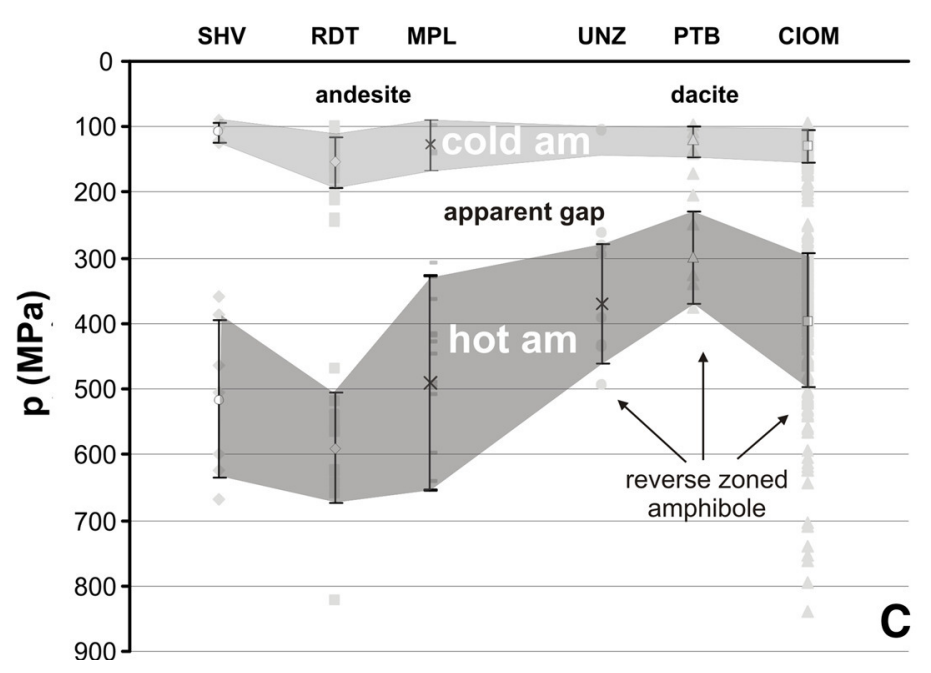

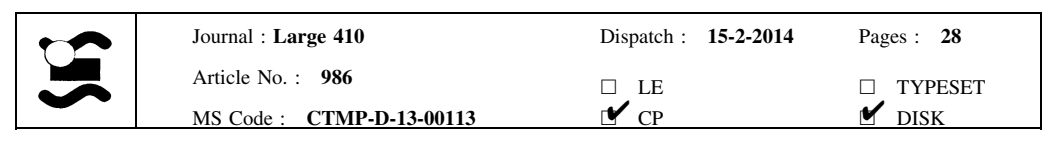




\section{Magma chamber architecture and petrogenesis of mixed intermediate magmas:}

1. based on the Ridolfi thermobarometry

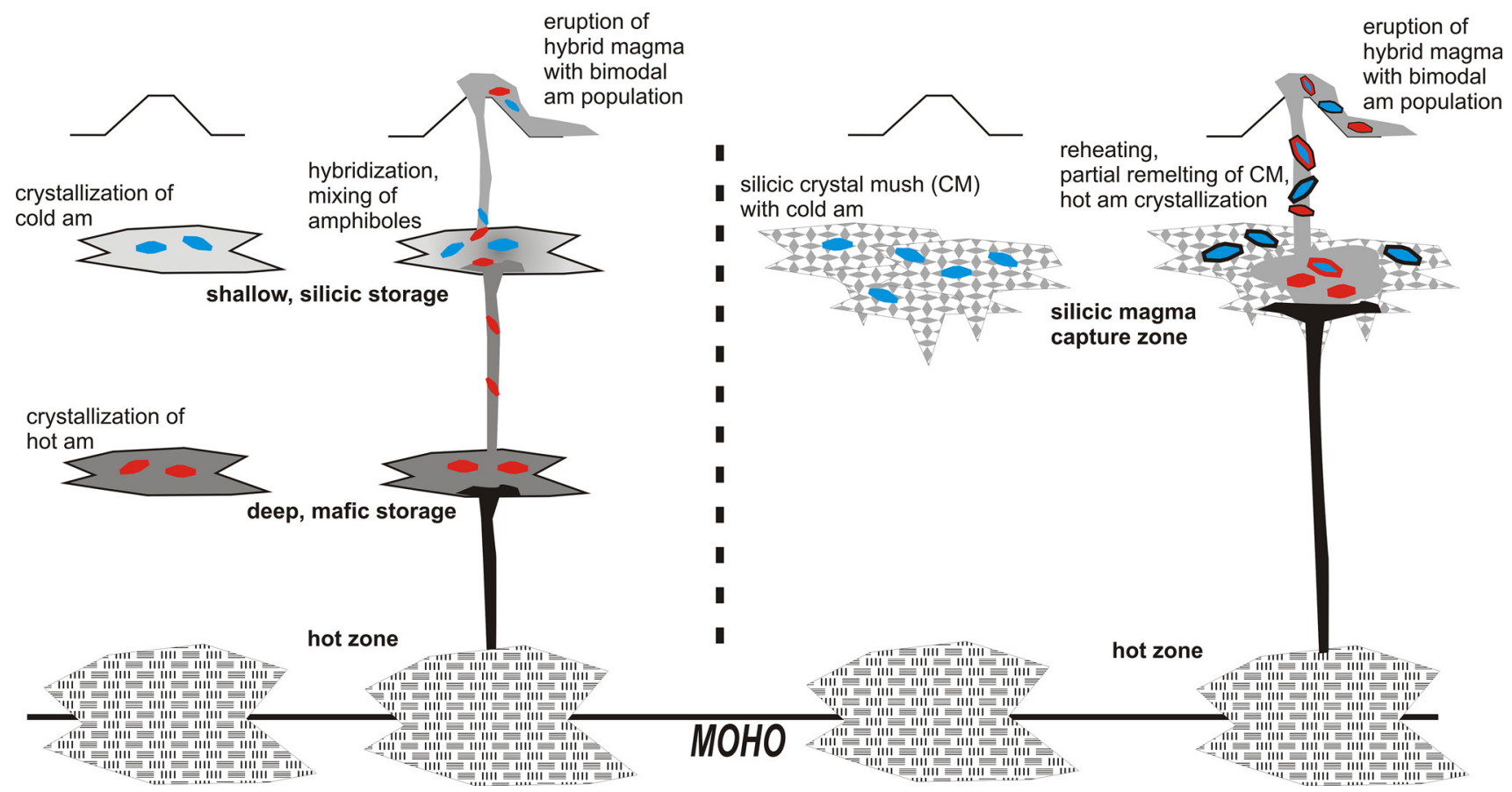

Fig. 14 Schematic cartoon that shows two different models for the inferred magma storage system and petrogenesis of mixed intermediate magmas based on bimodal amphibole populations. As it is

1075 as Ridolfi et al. (2010) may often yield unrealistic pressure 107 AQ4 variation and magma chamber architecture (Fig. 13).

Processes and conditions of magma mixing beneath andesite-dacite composite volcanoes-the amphibole perspective

1080 Intermediate mixed magmas of volcanic arcs often host 1081 almost the same bimodal amphibole cargo as it was 1082 observed in the Ciomadul dacites. Bimodal amphiboles 1083 characterize the erupted products of, e.g., Mt. Pinatubo 1084 (Pallister et al. 1996), Unzen (Sato et al. 1999, 2005), 1085 Soufriére Hills (Humphreys et al. 2009a), Redoubt (Wolf 1086 and Eichelberger 1997; Coombs et al. 2012), Mt. Pelée 1087 (Pichavant et al. 2002), and the Central Volcanic Zone 1088 dacites in Chile (Nakada 1991). Although the similar 1089 amphibole cargo may suggests similar processes and con1090 ditions beneath these volcanoes, several models have been 1091 established to explain the origin of the bimodal amphiboles 1092 (e.g., Pichavant et al. 2002; Coombs et al. 2012; Ridolfi 1093 et al. 2010; Sato et al. 1999; Koleszar and Kent 2011). Our 1094 amphibole perspective investigation indicates that bimodal 1095 amphibole populations cannot unambiguously mean crys1096 tallization at different depths as it is commonly indicated
2. based on our study

shown, only the second model provides realistic interpretation for the formation of simple-zoned and composite amphiboles. For further details, see the discussion. The figures are not to scale

(Pichavant et al. 2002; Ridolfi et al. 2010; Koleszar and Kent 2011; Chambefort et al. 2013), but an alternative model could be the remobilization of a long-lived, nearsolidus crystal mush by hot mafic magma intrusion (Nakamura 1995; Pallister et al. 1996; Murphy et al. 2000). This suggests that these volcanoes can be underlain by a shallow (100-300 MPa) storage zone where cold, silicic magmas are captured and low-Al amphiboles are formed. High-Al amphiboles can crystallize at shallow depth during reactivation and remobilization of this crystal mush due to mafic magma intrusion followed by hybridization of the different magmas (Fig. 14). The amphibole thermobarometry of Ridolfi et al. (2010) and Ridolfi and Renzulli (2012) seems to be useful in the case of mixed magmas in which equilibrium mineral phases are difficult to find as well as experiments are limited due to their mixed character. However, these equations lead to the same $\mathrm{p}-\mathrm{T}$ evolution path for all amphiboles along their stability curve; at the same time, bimodal amphiboles in mixed intermediate magmas usually not follow this trend, as it is demonstrated in this study. Thus, these formulations are unable to reproduce the conditions and $\mathrm{p}-\mathrm{T}$ path of mafic magma replenishment into shallow eruption feeder magma storage filled with cold silicic crystal mush, that is, however, a
1097

1098

1099

1100

1101

1102

1103

1104

1105

1106

1107

1108

1109

1110

1111

1112

1113

1114

1115

1116

1117

1118

1119

1120

\begin{tabular}{|l|lll|}
\hline & Journal : Large 410 & Dispatch : $\mathbf{1 5 - 2 - 2 0 1 4}$ & Pages : 28 \\
& Article No. : 986 & $\square$ LE & $\square$ TYPESET \\
MS Code : CTMP-D-13-00113 & $\boldsymbol{\sim}_{\mathrm{CP}}$ & $\checkmark$ DISK \\
\hline
\end{tabular}


commonly observed process in arc volcanoes (Nakamura 1995; Pallister et al. 1996; Murphy et al. 2000; Eichelberger et al. 2000).

\section{Conclusion}

The amphibole perspective of the studied Ciomadul's dacites suggesting that eruptions of the volcano were preceded by complex magma chamber processes. An important implication is that the erupted dacitic magma was formed in an upper crustal magma storage zone where reheating and partial remelting of silicic crystal mush occurred due to mafic magma replenishment days or weeks before the eruption. Our model is in contrast to the former view that suggested lower crustal conditions for the dacite genesis including continuous melting of the lower crust by mafic under platting and mixing - hybridization of mantleand crustal-derived magmas (Vinkler et al. 2007).

Our study highlights that without the knowledge of the processes that is responsible for the compositional variation of amphiboles, thermobarometers based on solely their chemistry can lead misleading conclusions on magma chamber architecture and conditions of the magma evolution.

Acknowledgments This research has been supported by the Hungarian Scientific Research Fund (OTKA No. 68587). Kiss Balázs in this research was supported by the European Union and the State of Hungary, co-financed by the European Social Fund in the framework of TÁMOP-4.2.4.A/2-11/1-2012-0001 'National Excellence Program'. Ioan Seghedi, Csaba Jánosi, and Alex Szakács provided invaluable help during the field trip campaigns. Fruitful discussions with Malcolm Rutherford, Filippo Ridolfi, Gerhard Wörner, Jon Blundy, and Olivier Bachmann at different stages of this study have helped to refine our model and clarify our ideas on amphibole formation and on the nature of the magma storage zone beneath intermediate volcanoes. M. Éva Jankovics are thanked for improvements in English and figures. Tamás Sági, Zsolt Bendő, and Franz Kiraly are acknowledged for help during SEM and EMPA analyses. Constructive comments provided by Olivier Bachmann and Michael J. Krawczynski and the editor Timothy L. Grove helped us to refine significantly the original manuscript.

\section{References}

Adam J, Oberti R, Camara F, Green TH (2007) An Electron microprobe, LAM-ICP-MS and single-crystal X-ray structure refinement study of the effects of pressure, melt- $\mathrm{H}_{2} \mathrm{O}$ concentration and $\mathrm{fO}_{2}$ on experimentally produced basaltic amphiboles. Eur J Mineral 19(5):641-655

Almeev RR, Ariskin AA, Ozerov AY, Kononkova NN (2002) Problems of the stoichiometry and thermobarometry of magmatic amphiboles: an example of hornblende from the andesites of Bezymyannyi volcano, Eastern Kamchatka. Geochem Int 40(8):723-738

Anderson JL, Smith DR (1995) The effects of temperature and $\mathrm{fO}_{2}$ on the Al-in-hornblende barometer. Am Mineral 80:549-559
Anderson JL, Barth AP, Wooden JL, Mazdab F (2008) Thermometers and thermobarometers in granitic systems. Rev Mineral Geochem 69(1):121-142

Bachmann O, Dungan MA (2002) Temperature-induced Al-zoning in hornblendes of the Fish Canyon magma, Colorado. Am Mineral 87(8-9):1062-1076

Barclay J, Carmichael ISE (2004) A hornblende basalt from Western Mexico: water-saturated phase relations constrain a pressuretemperature window of eruptibility. J Petrol 45(3):485-506

Blundy J, Cashman K (2008) Petrologic reconstruction of magmatic system variables and processes. Rev Mineral Geochem 69(1):179-239

Blundy JD, Holland TJB (1990) Calcic amphibole equilibria and a new amphibole-plagioclase geothermometer. Contrib Mineral Petrol 104(2):208-224

Browne BL (2005) Petrologic and experimental constraints on magma mixing and ascent: examples from Japan and Alaska. Ph.D. Thesis, University of Alaska Fairbanks

Browne BL, Gardner JE (2006) The influence of magma ascent path on the texture, mineralogy, and formation of hornblende reaction rims. Earth and Planetary Science Letters 246(3-4):161-176

Chalot-Prat F, Gîrbacea R (2000) Partial delamination of continental mantle lithosphere, uplift-related crust-mantle decoupling, volcanism and basin formation: a new model for the PlioceneQuaternary evolution of the southern East-Carpathians, Romania. Tectonophysics 327:83-107

Chambefort I, Dilles JH, Longo AA (2013) Amphibole geochemistry of the yanacocha volcanics, peru: evidence for diverse sources of magmatic volatiles related to gold ores. J Petrol 54(5):1017-1046

Coombs ML, Gardner JE (2004) Reaction rim growth on olivine in silicic melts: implications for magma mixing. Am Mineral 89(5-6):748-758

Coombs ML, Sisson TW, Bleick HA, Henton SM, Nye CJ, Payne AL, Cameron CE, Larsen JF, Wallace KL, Bull KF (2013) Andesites of the 2009 eruption of Redoubt Volcano, Alaska. J Volcanol Geoth Res 259:349-372

Costa F, Singer B (2002) Evolution of holocene dacite and compositionally zoned magma, volcán San Pedro, Southern Volcanic Zone, Chile. J Petrol 43(8):1571-1593

Costa F, Scaillet B, Pichavant M (2004) Petrological and experimental constraints on the pre-eruption conditions of holocene dacite from Volcán San Pedro ( $36^{\circ} \mathrm{S}$, Chilean Andes) and the importance of sulphur in silicic subduction-related magmas. J Petrol 45(4):855-881

Costa F, Andreastuti S, Bouvet de Maisonneuve C, Pallister JS (2013) Petrological insights into the storage conditions, and magmatic processes that yielded the centennial 2010 Merapi explosive eruption. J Volcanol Geotherm Res 261:209-235

Couch S, Sparks RSJ, Carroll MR (2001) Mineral disequilibrium in lavas explained by convective self-mixing in open magma chambers. Nature 411:1037-1039

De Angelis SH, Larsen J, Coombs M (2013) Pre-eruptive magmatic conditions at Augustine volcano, Alaska, 2006: evidence from amphibole geochemistry and texture. J Petrol 0(0):1-23

Eichelberger JC, Chertkoff DG, Dreher ST, Nye CJ (2000) Magmas in collision: rethinking chemical zonation in silicic magmas. Geology 28:603-606

Ernst WG, Liu J (1998) Experimental phase-equilibrium study of Aland Ti-contents of calcic amphibole in MORB - a semiquantitative thermobarometer. Am Mineral 83:952-969

Fillerup MA, Knapp JH, Knapp CC, Raileanu V (2010) Mantle earthquakes in the absence of subduction? Continental delamination in the Romanian Carpathians. Lithosphere 2(5):333-340

Gill JB (1981) Orogenic andesites and plate tectonics. Springer, Berlin 
Gîrbacea R, Frisch W (1998) Slab in the wrong place: lower lithospheric mantle delamination in the last stage of the Eastern Carpathian subduction retreat. Geology 26(7):611-614

Grove T, Elkins-Tanton L, Parman S, Chatterjee N, Müntener O, Gaetani G (2003) Fractional crystallization and mantle-melting controls on calc-alkaline differentiation trends. Contrib Mineral Petrol 145(5):515-533

Grove T, Baker M, Price R, Parman S, Elkins-Tanton L, Chatterjee N, Müntener O (2005) Magnesian andesite and dacite lavas from Mt. Shasta, northern California: products of fractional crystallization of H2O-rich mantle melts. Contrib Mineral Petrol 148(5):542-565

Hammarstrom JM, Zen E (1986) Aluminum in hornblende; an empirical igneous geobarometer. Am Mineral 71(11-12):1297-1313

Harangi S (2007) A Kárpát-Pannon térség legutolsó vulkáni kitörései-lesz-e még folytatás? (The last volcanic eruptions in the Carpathian-Pannonian Region-to be continued?). Földrajzi Közlemények 131(4):271-288

Harangi S, Lenkey L (2007) Genesis of the Neogene to Quaternary volcanism in the Carpathian-Pannonian region: role of subduction, extension, and mantle plume. Geol Soc Am Spec Pap 418:67-92

Harangi S, Mason PRD, Lukács R (2005) Correlation and petrogenesis of silicic pyroclastic rocks in the Northern Pannonian Basin, Eastern-Central Europe: in situ trace element data of glass shards and mineral chemical constraints. Journal of Volcanology and Geothermal Research 143(237-257)

Harangi S, Molnár M, Vinkler AP, Kiss B, Jull ATJ, Leonard AG (2010) Radiocarbon dating of the last volcanic eruptions of Ciomadul Volcano, Southeast Carpathians, Eastern-Central Europe. Radiocarbon 52(3):1498-1507

Holland T, Blundy J (1994) Non-ideal interactions in calcic amphiboles and their bearing on amphibole-plagioclase thermometry. Contrib Mineral Petrol 116:433-447

Holtz F, Johannes W, Tamic N, Behrens H (2001) Maximum and minimum water contents of granitic melts generated in the crust: a re-evaluation and implications. Lithos 56:1-14

Holtz F, Sato H, Lewis J, Benrens H, Nakada S (2005) Experimental petrology of the 1991-1995 Unzen dacite, Japan. Part I: phase relations, phase composition and pre-eruptive conditions. J Petrol 46(2):319-337

Humphreys MCS, Blundy JD, Sparks RSJ (2006) Magma evolution and open-system processes at Shiveluch volcano: insights from phenocryst zoning. J Petrol 47(12):2303-2334

Humphreys M, Christopher T, Hards V (2009a) Microlite transfer by disaggregation of mafic inclusions following magma mixing at Soufriere Hills volcano, Montserrat. Contrib Mineral Petrol 157(5):609-624

Humphreys MCS, Edmonds M, Christopher T, Hards V (2009b) Chlorine variations in the magma of Soufrière Hills volcano, Montserrat: insights from $\mathrm{Cl}$ in hornblende and melt inclusions. Geochim Cosmochim Acta 73(19):5693-5708

Jarosewich E, Nelen JA, Norberg JA (1980) Reference samples for electron microprobe analysis. Geostand Newsl 4:43-47

Johnson MC, Rutherford MJ (1989a) Experimental calibration of the aluminum-in-hornblende geobarometer with application to Long Valley caldera (California) volcanic rocks. Geology 17(9):837-841

Johnson MC, Rutherford MJ (1989b) Experimentally determined conditions in the Fish Canyon Tuff, Colorado, magma chamber. J Petrol 30(3):711-737

Karátson D, Telbisz T, Harangi S, Magyari E, Dunkl I, Kiss B, Jánosi C, Veres D, Braun M, Fodor E, Biró T, Kósik S, von Eynatten H, Lin D (2013) Morphometrical and geochronological constraints on the youngest eruptive activity in East-Central Europe at the
Ciomadul (Csomád) lava dome complex, East Carpathians. J Volcanol Geotherm Res 255:43-56

Kent AJR, Darr C, Koleszar AM, Salisbury MJ, Cooper KM (2010) Preferential eruption of andesitic magmas through recharge filtering. Nat Geosci 3(9):631-636

Koleszar AM, Kent AJR (2011) Compositional diversity and plumbing systems: evidence from amphiboles from Mount Hood, Oregon. AGU abstract \#V52A-01

Koleszar AM, Kent AJR, Wallace PJ, Scott WE (2012) Controls on long-term low explosivity at andesitic volcanoes: insights from Mount Hood, Oregon. J Volcanol Geotherm Res 219-220:1-14

Krawczynski M, Grove T, Behrens H (2012) Amphibole stability in primitive arc magmas: effects of temperature, $\mathrm{H} 2 \mathrm{O}$ content, and oxygen fugacity. Contrib Mineral Petrol 164(2):317-339

Larsen J (2006) Rhyodacite magma storage conditions prior to the 3430 yBP caldera-forming eruption of Aniakchak volcano, Alaska. Contrib Mineral Petrol 152(4):523-540

Leake BE, Woolley AR, Arps CES, Birch WD, Gilbert MC, Grice JD, Hawthorne FC, Kato A, Kisch HJ, Krivovichev VG, Linthout K, Laird J, Mandarino JA, Maresch WV, Nickel EH, Rock NMS, Schumacher JC, Smith DC, Stephenson NCN, Ungaretti L, Whittaker EJC, Youzhi G (1997) Nomenclature of amphiboles: report of the subcommittee on amphiboles of the International Mineralogical Association, commission on new minerals and mineral names. Can Mineral 35:219-246

Pécskay Z, Lexa J, A. S, Balogh K, Seghedi I, Konecny V, Kovács M, Márton E, Kaliciak M, Széky-Fux V, Póka T, Gyarmati P, Edelstein O, Rosu E, Zec B (1995) Space and time distribution of Neogene-Quaternary volcanism in the Carpatho-Pannonian Region. In: Downes H, Vaselli O (eds) Neogene and Related Magmatism in the Carpatho-Pannonian Region, vol 7. pp 15-28

Lorinczi P, Houseman GA (2009) Lithospheric gravitational instability beneath the Southeast Carpathians. Tectonophysics 474(1-2):322-336

Martel C, Pichavant M, Holtz F, Scaillet B, Bourdier J-L, Traineau H (1999) Effects of $\mathrm{fO}_{2}$ and $\mathrm{H}_{2} \mathrm{O}$ on andesite phase relations between 2 and 4 kbar. J Geophys Res Solid Earth 104(B12):29453-29470

Mason PRD, Kraan WJ (2002) Attenuation of spectral interferences during laser ablation inductively coupled plasma mass spectrometry (LA-ICP MS) using an rf only collision and reaction cell. J Anal At Spectrom 17:858-867

Mason PRD, Downes H, Thirlwall M, Seghedi I, Szakács A, Lowry D, Mattey D (1996) Crustal assimilation as a major petrogenetic process in the East Carpathian Neogene and Quaternary continental margin arc, Romania. J Petrol 37(4):927-959

Mason PRD, Seghedi I, Szakács A, Downes H (1998) Magmatic constraints on geodynamic models of subduction int he East Carpathians, Romania. Tectonophysics 297:157-176

McGuire AV, Francis CA, Dyar Darby M (1992) Mineral standards for electron microprobe analysis of oxygen. Am Mineral 77:1087-1091

Miyashiro A (1974) Volcanic rock series in island arcs and active continental margins. Am J Sci 274:321-355

Murphy MD, Sparks RSJ, Barclay J, Caroll MR, Brewer TS (2000) Remobilization of Andesite Magma by Intrusion of Mafic Magma at the Soufriere Hills Volcano, Montserrat, West Indies. J Petrol 41(1):21-42

Nakada S (1991) Magmatic processes in titanite-bearing dacites, Central Andes of Chile and Bolivia. Am Mineral 76(3-4):548-560

Nakamura N (1974) Determination of REE, Ba, Fe, Mg, Na and K in carbonaceous and ordinary chondrites. Geochim Cosmochim Acta 38(5):757-775

Nakamura M (1995) Continuous mixing of crystal mush and replenished magma in the ongoing Unzen eruption. Geology 23(9):807-810

\begin{tabular}{|c|c|c|c|c|}
\hline & Journal : Large 410 & Dispatch & 15-2-2014 & Pages: $\mathbf{2 8}$ \\
\hline & $\begin{array}{l}\text { Article No. : } 986 \\
\text { MS Code : } \quad \text { CTMP-D-13-00113 }\end{array}$ & $\begin{array}{l}\square \quad \mathrm{LE} \\
\boldsymbol{\sim}_{\mathrm{CP}} \\
\end{array}$ & & $\begin{array}{ll}\square & \text { TYPESET } \\
\boldsymbol{V} \\
\text { DISK }\end{array}$ \\
\hline
\end{tabular}


Pallister JS, Hoblitt RP, Meeker GP, Knight RJ, Siems DF (1996) Magma mixing at Mount Pinatubo: petrographic and chemical evidence from the 1991 deposits. In: Newhall CG, Punongbayan RS (eds) Fire and Mud: Eruptions and Lahars of Mount Pinatubo, Philippines. Seattle and London, pp 687-731

Pallister JS, Thornber CR, Cashman KV, Clynne MA, Lowers HA, Mandeville CW, Brownfield IK, Meeker GP (2008) Petrology of the 2004-2006 Mount St. Helens lava dome-implications for magmatic plumbing and eruption triggering. In: Sherrod DR, Scott WE, Stauffer PH (eds) A volcano rekindled: the renewed eruption of mount St. Helens, 2004-2006, vol 1750. pp 674-702

Pearce NJG, Perkins WT, Westgate JA, Gorton MP, Jackson SE, Neal CR, Chenery SP (1997) A compilation of new and published major and trace element data for NIST SRM 610 and NIST SRM 612 glass reference materials. Geostand Newsl 21:115-144

Peltz S, Vajdea E, Balogh K, Pécskay Z (1987) Contributions to the geochronological study of the volcanic processes int he Calimani and Hargitha Mountains (East Carpathians, Romania). Dari de Seama ale Sedintelor Institutul de Geologie si Geofizica 72-73:323-338

Pichavant M, Martel C, Bourdier J-L, Scaillet B (2002) Physical conditions, structure, and dynamics of a zoned magma chamber: mount Pelée (Martinique, Lesser Antilles Arc). J Geophys Res 107(B5):1-28

Popa M, Radulian M, Szakács A, Seghedi I, Zaharia B (2012) New seismic and tomography data in the southern part of the Harghita mountains (Romania, Southeastern Carpathians): connection with recent volcanic activity. Pure appl Geophys 169(9):1557-1573

Ren Y, Stuart GW, Houseman GA, Dando B, Ionescu C, Hegedüs E, Radovanović S, Shen Y (2012) Upper mantle structures beneath the Carpathian-Pannonian region: implications for the geodynamics of continental collision. Earth Planet Sci Lett 349-350:139-152

Reubi O, Blundy J (2009) A dearth of intermediate melts at subduction zone volcanoes and the petrogenesis of arc andesites. Nature 461:1269-1273

Ridolfi F, Renzulli A (2012) Calcic amphiboles in calc-alkaline and alkaline magmas: thermobarometric and chemometric empirical equations valid up to $1,130^{\circ} \mathrm{C}$ and $2.2 \mathrm{GPa}$. Contrib Mineral Petrol 163(5):877-895

Ridolfi F, Renzulli A, Puerini M (2010) Stability and chemical equilibrium of amphibole in calc-alkaline magmas: an overview, new thermobarometric formulations and application to subduction-related volcanoes. Contrib Mineral Petrol 160(1):45-66

Ruprecht P, Bachmann O (2010) Pre-eruptive reheating during magma mixing at Quizapu volcano and the implications for the explosiveness of silicic arc volcanoes. Geology 38:919-922

Rutherford MJ, Devine JD (1988) The May 18, 1980, eruption of Mount St. Helens Stability and chemistry of amphiboles in the magma chamber. J Geophys Res 93(B10):11949-11959

Rutherford MJ, Devine JD (2003) Magmatic conditions and magma ascent as indicated by hornblende phase equilibria and reactions in the 1995-2002 Soufrière hills magma. J Petrol 44(8):1433-1453

Rutherford MJ, Devine JD (2008) Magmatic conditions and processes in the storage zone of the 2004-2006 Mount St. Helens Dacite. In: Sherrod DR, Scott WE, Stauffer PH (eds) A volcano rekindled: the renewed eruption of Mount St. Helens, 2004-2006, vol 1750. pp 703-725

Rutherford MJ, Hill PM (1993) Magma ascent rates from amphibole breakdown: an experimental study applied to the 1980-1986 Mount St. Helens eruptions. J Geophys Res 98(B11):19667-19685

Sato H, Nakada S, Fujii T, Nakamura M, Suzuki-Kamata K (1999) Groundmass pargasite in the 1991-1995 dacite of Unzen volcano: phase stability experiments and volcanological implications. J Volcanol Geotherm Res 89(1-4):197-212

Sato H, Holtz F, Behrens H, Botcharnikov R, Nakada S (2005) Experimental petrology of the 1991-1995 Unzen dacite, Japan. Part II: cl/OH partitioning between hornblende and melt and its implications for the origin of oscillatory zoning of hornblende phenocrysts. J Petrol 46(2):339-354

Scaillet B, Evans BW (1999) The 15 June 1991 eruption of Mount Pinatubo. I. phase equilibria and pre-eruption $\mathrm{P}-\mathrm{T}-\mathrm{fO}_{2}-\mathrm{fH}_{2} \mathrm{O}$ conditions of the dacite magma. J Petrol 40(3):381-411

Schmidt MW (1992) Amphibole composition in tonalite as a function of pressure: an experimental calibration of the Al-in-hornblende barometer. Contrib Mineral Petrol 110(2-3):304-310

Scott JAJ, Mather TA, Pyle DM, Rose WI, Chigna G (2012) The magmatic plumbing system beneath Santiaguito volcano, Guatemala. J Volcanol Geotherm Res 237-238:54-68

Seghedi I, Szakács A, Udrescu C, Stoian M, Grabari G (1987) Trace element geochemistry of the South Hargitha volcanics (East Carpathians): calc-alkaline and shoshonitic association. Dari de Seama ale Sedintelor Institutul de Geologie si Geofizica 72-73:381-397

Seghedi I, Maţenco L, Downes H, Mason PRD, Szakács A, Pécskay Z (2011) Tectonic significance of changes in post-subduction Pliocene-Quaternary magmatism in the south east part of the Carpathian-Pannonian Region. Tectonophysics 502(1-2):146-157

Shane P, Smith VC (2013) Using amphibole crystals to reconstruct magma storage temperatures and pressures for the post-caldera collapse volcanism at Okataina volcano. Lithos 156-159:159-170

Simakin AG, Salova TP, Babansky AD (2009) Amphibole crystallization from a water-saturated andesite melt: experimental data at $\mathrm{P}=2$ kbar. Petrology 17(6):591-605

Simakin A, Zakrevskaya O, Salova T (2012) Novel Amphibole Geobarometer with Application to Mafic Xenoliths. Earth Sci Res 1(2):82-97

Sisson TW, Grove TL (1993) Experimental investigations of the role of $\mathrm{H}_{2} \mathrm{O}$ in calc-alkaline differentiation and subduction zone magmatism. Contrib Mineral Petrol 113(2):143-166

Streck MJ (2008) Mineral Textures and Zoning as Evidence for Open System Processes. In: Putirka KD, Tepley III FJ (eds) Reviews in Mineralogy and Geochemistry, vol 69. Mineralogical Society of America \& Geochemical Society, pp 595-622

Sun S-s, McDonough WF (1989) Chemical and isotopic systematics of oceanic basalts: implications for mantle composition and processes. Geol Soc Lond Spec Publ 42(1):313-345

Szakács A, Seghedi I (1986) Chemical diagnosis of the volcanics from the southeasternmost part of the Harghita Mountainsproposal for a new nomenclature. Revue Roumaine de Géologie 30:41-48

Szakács A, Seghedi I (1995) The Călimani-Gurghiu-Harghita volcanic chain, East Carpathians, Romania: volcanological features. Acta Vulcanol 7(2):145-153

Szakács A, Seghedi I (2013) The relevance of volcanic hazard in Romania: is there any? Environ Eng Manag J 12:125-135

Szakács A, Seghedi I, Pécskay Z (1993) Peculiarities of South Harghita Mts. as the terminal segment of the Carpathian Neogene to Quaternary volcanic chain. Revue Roumaine de Géologie Géophysique et Géographie, Géologie 37:21-37

Szakács A, Seghedi I, Pécskay Z (2002) The most recent volcanism in AQ1 the Carpathian-Pannonian Region. Is there any volcanic hazard? In: The XVIIth Congress of Carpathian-Balkan Geological Association, vol 53. Geologica Carpathica, Bratislava, Slovakia, pp 193-194

Thornber CR, Pallister JS, Lowers HA, Rowe MC, Mandeville CW, Meeker GP (2008) Chemistry, mineralogy, and petrology of 
amphibole in Mount St. Helens 2004-2006 dacite. In: Sherrod DR, Scott WE, Stauffer PH (eds) A Volcano rekindled: the renewed eruption of Mount St. Helens, 2004-2006, vol 1750. pp 727-754

Turner SJ, Izbekov P, Langmuir C (2013) The magma plumbing system of Bezymianny Volcano: insights from a 54 year time series of trace element whole-rock geochemistry and amphibole compositions. J Volcanol Geotherm Res 263:108-121

Vaselli O, Minissale A, Tassi F, Magro G, Seghedi I, Ioane D, Szakács A (2002) A geochemical traverse across the Eastern Carpathians (Romania): constraints on the origin and evolution of the mineral water and gas discharges. Chem Geol 182(2-4):637-654

Viccaro M, Ferlito C, Cristofolini R (2007) Amphibole crystallization in the Etnean feeding system: mineral chemistry and trace element partitioning between $\mathrm{Mg}$-hastingsite and alkali basaltic melt. Eur J Mineral 19(4):499-511

Vinkler AP, Harangi S, Ntaflos T, Szakács A (2007) A Csomád vulkán (Keleti-Kárpátok) horzsaköveinek kőzettani és geokémiai vizsgálata-petrogenetikai következtetések (Petrology and geochemistry of pumices from the Ciomadul volcano (Eastern Carpathians)_implications for petrogenetic processes). Földtani Közlöny (Bull. Hung. Geol. Soc.) 137(1):103-128

Vyhnal CR, McSween HY, Speer JA (1991) Hornblende chemistry in southern Appalachian granitoids: implications for aluminum hornblende thermobarometry and magmatic epidote stability. Am Mineral 76:176-188

Walker B Jr, Klemetti E, Grunder A, Dilles J, Tepley F, Giles D (2013) Crystal reaming during the assembly, maturation, and waning of an eleven-million-year crustal magma cycle: thermobarometry of the Aucanquilcha Volcanic Cluster. Contrib Mineral Petrol 165(4):663-682

Wolf KJ, Eichelberger JC (1997) Syneruptive mixing, degassing, and crystallization at Redoubt Volcano, eruption of December, 1989 to May 1990. J Volcanol Geoth Res 75(1-2):19-37

\begin{tabular}{|l|lll|}
\hline Journal : Large 410 & Dispatch : 15-2-2014 & Pages : 28 \\
Article No. : 986 & $\square$ LE & $\square$ TYPESET \\
MS Code : CTMP-D-13-00113 & $\sim_{\text {CP }}$ & $\checkmark$ DISK \\
\hline
\end{tabular}


Journal : 410

Article : 986

\section{Author Query Form}

照 Springer

the language of science

\section{Please ensure you fill out your response to the queries raised below and return this form along with your corrections}

\section{Dear Author}

During the process of typesetting your article, the following queries have arisen. Please check your typeset proof carefully against the queries listed below and mark the necessary changes either directly on the proof/online grid or in the 'Author's response' area provided below

\begin{tabular}{|l|l|l|}
\hline Query & Details Required & Author's Response \\
\hline AQ1 & $\begin{array}{l}\text { References Vinkler et al. (1997), Bachmann et al. (2002), Angelis (2013), Krawczinsky et al. (2012) and } \\
\text { Coombs et al. (2012) are cited in text but not provided in the reference list. Please provide references in } \\
\text { the list or delete these citations. }\end{array}$ & \\
\hline AQ2 & Please check the layout of Tables 1, 2 and 3, and correct if necessary. & $\begin{array}{l}\text { Please check and confirm the inserted citation of Fig. 13 is correct. If not, please suggest an alternative } \\
\text { citation. Please note that figures and tables should be cited in sequential order in the text. }\end{array}$ \\
\hline AQ3 & Shane and Smith (2012) has been changed to Shane and Smith (2013) so that this citation matches the list. & \\
\hline AQ4 & $\begin{array}{l}\text { Zease check and confirm the author names and initials are correct in the references Hammarstrom and } \\
\text { AQ56) }\end{array}$ & $\begin{array}{l}\text { Please provide complete details for reference Pallister et al. (1996, 2008), Pécskay et al. (1995) and } \\
\text { Thornber et al. (2008). }\end{array}$ \\
\hline AQ6 & Please provide page range for reference Harangi et al. (2005). & \\
\hline AQ7 & Please provide publisher name and location for reference Rutherford and Devine (2008). & \\
\hline AQ8 & Please provide publisher location for reference Streck (2008). & \\
\hline AQ10 & Please provide editor names for reference Szakacs et al. (2002). & \\
\hline
\end{tabular}

